Article

\title{
Relationships between sediment transport and various hydrological and hydraulic characteristics of flood events on Trotuş River (Romania)
}

\author{
Dan Dumitriu ${ }^{1 *}$ \\ 1 Department of Geography, Faculty of Geography and Geology, Alexandru Ioan Cuza University of \\ Iasi (UAIC), RO -700505 Iasi, Romania; dndumitriu@yahoo.com \\ * Correspondence: dndumitriu@yahoo.com; Tel.: +40-740-133-237
}

\begin{abstract}
Sediment transport is highly sensitive to flow conditions, showing significant increase during flood events. Based on this principle, this study set out to rank flood events occurring along river Trotus (Romania) based on the amount of transported sediment and event duration. The 77 flood events recorded from 2000 to 2017 were ranked into 4 classes: type A (4\%); type B (16\%), type C (14\%) and type D (66\%). The sediment transport specific for the 4 types of flood events was related to the flow discharge (sediment rating curve and hysteresis effect), the specific stream power and the energy expenditure of these events. More than $60 \%$ of the hysteresis loops typical for flood events were clockwise, thus singling out the channel as the main sediment source. Ca. $74 \%$ of the total sediment yield was transported at stream power values higher than the $300 \mathrm{Wm}^{-2}$ threshold, which was exceeded in less than $1 \%$ of the investigated timeframe. The changes occurring in the sediment transport rates after major floods show that these events are significant thresholds in the hydrogeomorphic evolution of river channels.
\end{abstract}

Keywords: flood; sediment transport; sediment rating curve; hysteresis loop; stream power; maximum flow efficiency; energy generated by the flood.

\section{Introduction}

During the past decade, against the backdrop of global climate changes, an increasing number of high quality studies tackling sediment transport have been published [1,2,3,4]. The sediment regime on any given stream is determined by four types of interconnected controls: (i) meteorological and hydrological factors; (ii) disruptions in landform stability (e.g., natural landslides); (iii) anthropogenic activities and (iv) changes of sediment sources [5,6,7]. In this study the focus was placed on the first category of controls due to the recent marked increase in extreme precipitation events, both in terms of frequency and intensity, with direct repercussions on flood events [8]. In addition, the highest amounts of sediment are transported during such flood events when the kinetic energy of the stream is sufficient for sediment displacement and transfer $[9,10]$.

The total sediment load during flood events, comprising the suspended load and the bedload, is highly significant for the spatial-temporal changes of stream channels $[11,12]$. Whereas the suspended load is dominant at low to medium flows, the bedload deposited on the channel bed is removed and transferred by flows higher than $50-60 \%$ of the bankfull flow $[13,14]$. The highest degree of displacement of the bedload occurs at discharges higher than the bankfull flow [15], therefore we selected the flood events where the bankfull flow was exceeded. The most frequent values of the bedload to total solid load ratio documented in the literature range from 10 to $20 \%$ [11]. However, direct bedload gauging is difficult, therefore these measurements are rather rare for the majority of alluvial streams [16]. Moreover, various indirect methods are used for estimating bedload values, including the Bedload Assessment for Gravel-bed Streams (BAGS) software [17]. 
The largest share of the total sediment load is held by the suspended load, such that the latter is regarded as the main global mechanism of fluvial sediment transport [18]. Flood events are often accompanied by intense soil erosion processes, which account for the large amounts of suspended alluvium transported during these events [19].

Firstly, the suspended load is closely linked to the streamflow discharge of fluvial systems [20]. The relation between the suspended sediment concentration (SSC) and the flow discharge (Q) is illustrated by the sediment rating curve (SRC) [21]. Various studies show that flood events can alter to a significant degree the relation between $Q$ and SSC [22,23]. During flood events, the relation between SSC and Q can exhibit a hysteresis-type of behavior generated by the time gap between the peaks of the sediment load and the flow [22,24,25]. Hysteresis loop patterns are determined by the location of sediment sources: in the catchment, in the channel bed or the river banks [26].

In addition to the flow (albeit in close connection with it), the sediment transport was investigated in relation to various energy parameters, such as the specific stream power. The latter, defined as the time rate of potential energy expenditure per unit weight of water, has been documented as the major factor determining the total sediment concentration [27]. Thus, specific stream power can be regarded as an extremely useful index for studying fluvial sediment transport, and has been widely employed for assessing sediment transport [28]. Although specific stream power and energy expenditure have been used mainly for the bedload [29,30], in some instances they were correlated with the suspended load [31], as well.

In the case of Romanian rivers, the studies assessing the sediment transport during flood events $[32,33,34]$ are rather scarce, whereas the papers tackling climatic and hydrological conditions prompting the occurrence of flood events or associated risk phenomena are more numerous [35 - 38].

The main objectives of this study consisted in: (1) estimating bedload sediment transport rates during the flood event; (2) ranking flood events which exceeded bankfull discharge (Qbf) values in terms of magnitude, duration and amount of transported sediment; (3) assessing the relation between the sediment load and the discharge based on the sediment rating curve and the hysteresis effect; (4) determining, according to each type of flood event, the connection between the sediment transport during flood events and some energy parameters (specific stream power, energy expenditure, maximum flow efficiency).

\section{Materials and Methods}

\subsection{Study area}

Trotuș River is a major tributary of Siret River, which, in turn, is the largest tributary of the Danube within the Romanian territory. Trotus drainage basin overlies the central areas of the Eastern Carpathians and the Moldavian Subcarpathians (Figure 1), extending over $4500 \mathrm{~km}^{2}$. Trotus, is a gravel bed river along its entire $150 \mathrm{~km}$ length. The most significant characteristics of the study area are listed in Table 1. The substrate underlying the drainage basin pertains to four distinct structural-lithological units: the crystalline-Mesozoic zone (crystalline schists, limestone, dolomite) (Figure 1Ba), the Carpathian flysch (sandstone, marls, clay) (Figure 1Bb), the pericarpathian molasse (clays, marls, sandstone) (Figure 1Bc) and the foreland or platform (sand, clays, sandstone, gravel) (Figure 1Bd). The highest effective erosion and sediment yield rates are documented in the molasse and foreland zones [39], due to the ample human intervention affecting the hillslopes. The river hydrology is dominated by frequent spring floods determined by overlapping snowmelt and high precipitation, typically low to medium in magnitude, as well as by more infrequent flood events of large magnitude generated by prolonged summer precipitation. Sediment transport along Trotus River exhibits distinctive traits compared to other rivers east of the Eastern Carpathians. These variations are caused by: (i) the most intense activity in terms of precipitation of retrograde cyclones from the Black Sea in Eastern Romania [40]; (ii) the relative proximity of the study area to Vrancea seismic zone, thus affecting erosion rates. In the neighboring Putna drainage basin, located to the south, the erosion rates are among the highest documented in the temperate region of Europe [41]; 
(iii) massive deforestation, both after WW2, as well as after 1990 [42]; (iv) minor changes of the channel bed (one reservoir, located on a tributary, few gravel pits).

Table 1. Main characteristics of Trotuș drainage basin and channel at gauging stations

\begin{tabular}{lcccc}
\hline \multicolumn{1}{c}{ Parameter } & Lunca de Sus & Goioasa & Târgu Ocna & Vrânceni \\
\hline Basin area, $\mathrm{km}^{2}$ & 88 & 780 & 2090 & 4090 \\
Average elevation, $\mathrm{m}$ & 1140 & 1052 & 924 & 734 \\
Distance to the river mouth, $\mathrm{km}$ & 146 & 106 & 69 & 37 \\
Channel bed slope, $\mathrm{mm}^{-1}$ & 0.02 & 0.07 & 0.05 & 0.03 \\
Annual precipitation, $\mathrm{mm}$ & 602 & 636 & 592 & 523 \\
Maximum water discharge, $\mathrm{m}^{3} \mathrm{~s}^{-1}$ & 23.5 & 353 & 1490 & 2845 \\
Mean water discharge, $\mathrm{m}^{3} \mathrm{~s}^{-1}$ & 0.88 & 6.5 & 17 & 35 \\
Bankfull discharge & 8 & 63 & 170 & 325 \\
D50 surface sediment, $\mathrm{mm}$ & 75 & 95 & 119 & 43 \\
\hline
\end{tabular}

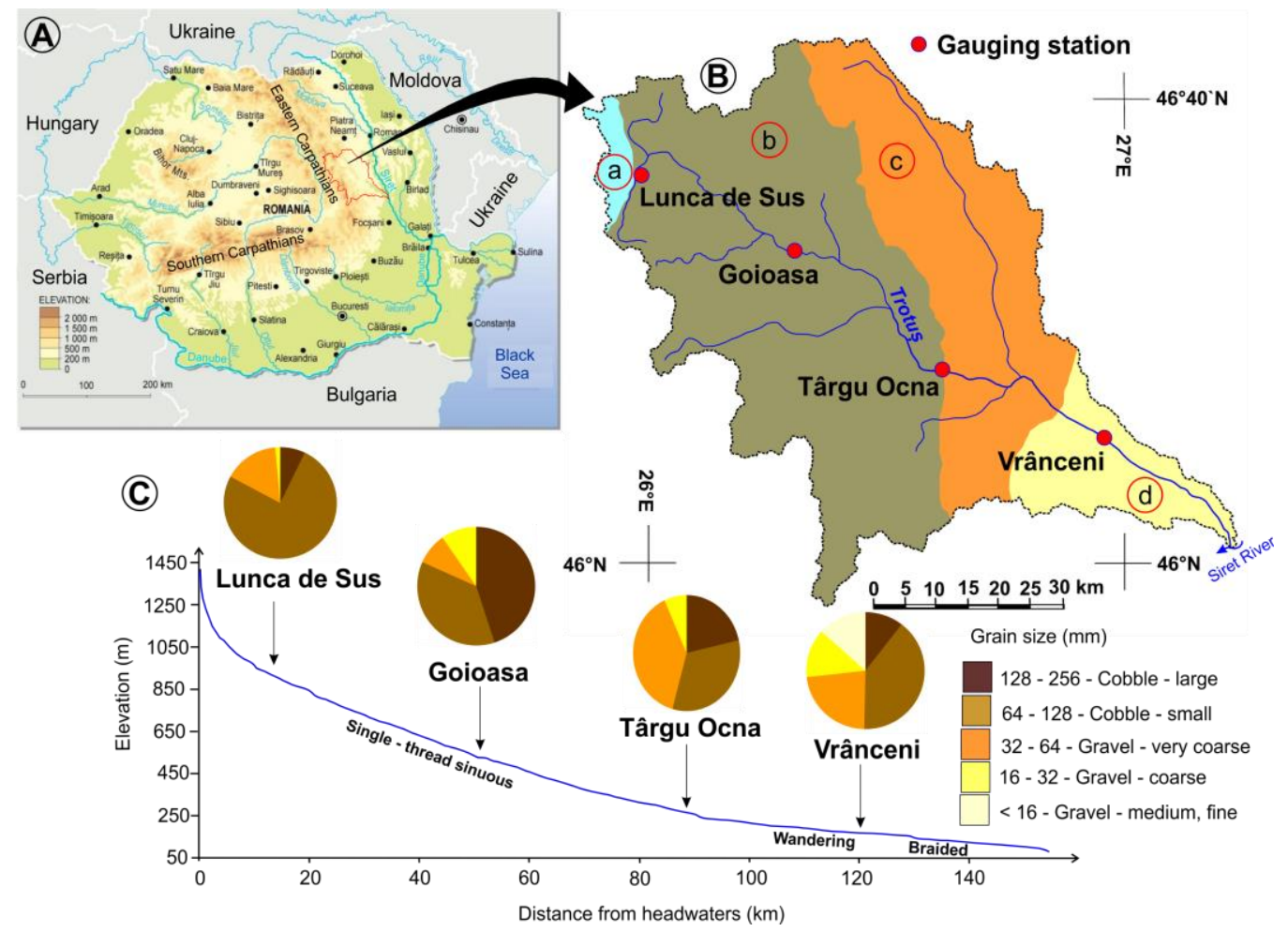

Figure 1. A. Location of Trotuș River basin in Romania; B. Trotuş River basin - location of gauging stations and major lithological-structural units: (a) crystalline-Mesozoic zone; (b) East Carpathian flysch zone; (c) pericarpathian molasse zone; (d) foreland zone; C. Longitudinal profile of Trotuș River, comprising the grain size of surface deposits in the analyzed sections and the type of channel.

\subsection{Data sources}

The data regarding the daily mean flow discharge and sediment load from 2000 to 2017 are provided by the "Romanian Waters" National Administration - Siret Water Branch, which manages the four gauging stations included in this study (Lunca de Sus - LS, Goioasa - GO, Târgu Ocna - TO și Vrânceni-VR).

The bedload sediment transport was estimated using the Bedload Assessment for Gravel-bed Streams (BAGS) software developed by the US Forest Service [17]. BAGS is an Excel-based sediment transport model and pertains to the public domain (open-source software). A surface-based bedload transport equation [43] was the most suitable for the specific conditions of Trotuş River. The 
parameters utilized for estimating the bedload based on this model included the grain size distribution of the channel bed surface [44,45,46], the cross-section profile of the channel in the analysed reach, the average slope gradient of the channel bed, the flow discharge and Manning' $\mathrm{s}$ " $\mathrm{n}$ " values estimated from Chow (1959) [47]. The data yielded by BAGS were used to assess the total sediment load according to the type of flood event or in relation to various energy parameters.

\subsection{Methods}

In most instances, investigations on flood fequency focused mainly on extreme events, and to a lesser degree on more frequent, moderate magnitude events which leave a lasting mark on channel bed morphology, and therefore should be of particular interest to geomorphologists [48]. Based on this argument, we included in the analysis all flood events which reached or exceeded the bankfull discharge.

Consequently, all the flood events recorded between 2000 and 2017 which reached or surpassed the bankfull discharge were ranked according to the classification introduced by Costa and O'Connor (1995) [49] and adapted to sediment transport by Sear (2003) [50]. Thus, Sear (2003) defined the following types of floods depending on the magnitude, duration and amount of transported sediment: (i) type $A$, specific for short duration and high magitude events, where the sediment source area consists mainly of the channel (banks, channel bed), during which relatively large amounts of alluvium are transported; (ii) type $B$, characteristic for events with both ample duration an magnitude, which carry the largest amounts of sediment due to the diversification of source areas (channel, hillslopes); (iii) type C, specific for flood events with long duration and moderate magnitude where the channel-catchment connectivity generates a significant amount of transported alluvium; (iv) type $D$, where both the stream power and the transported sediment have low values.

The unit stream power is a measure of the river capacity to transport sediments at a certain flow discharge and is quantized using eq. [51]:

$$
\omega=\Omega / w=\gamma Q S / w,
$$

where $\omega\left(\mathrm{Wm}^{-2}\right)$ is the unit stream power, $\Omega\left(\mathrm{Wm}^{-1}\right)$ - the total stream power per unit of length, $\mathrm{w}(\mathrm{m})$ - length of wetted perimeter, $\gamma$ - specific weight of water $\left(9810 \mathrm{Nm}^{-1}\right), \mathrm{Q}\left(\mathrm{m}^{3} \mathrm{~s}^{-1}\right)-$ flow discharge.

In this study the minimum threshold of stream power $\left(300 \mathrm{Wm}^{-2}\right)$ associated to major geomorphic changes of the channel is the one defined by Magilligan (1992) [52], also known as the Miller - Magilligan threshold.

The total energy generated by the flood, as well as the average energy per unit area $(\Omega)$ that was expended over the duration of the floods are closely related to the stream power. The former parameter was calculated by estimating the area below the stream power plot, whereas the latter was computed using the equation elaborated by Costa and O'Connor (1995):

$$
\Omega=\int \gamma \mathrm{QS} / \mathrm{wdt},
$$

where $\mathrm{t}$ - duration (s), $\Omega$ - total energy expended during the flood event $\left(\mathrm{Js}^{-1}\right)$.

The suspended sediment rating curve (SRC) is based on an empirical correlation between sediment concentration and the flow discharge. This correlation can be expressed either in the shape of log sediment load (Qs) or log concentration (Co) versus log discharge (Q), or as a power function $[21,53,54]$ :

$$
\mathrm{Qs}=\mathrm{aQ}^{\mathrm{b}} \text {, }
$$

where Qs is the rate of the suspended sediment load; $\mathrm{a}$ - regression coefficient; $\mathrm{b}$ - regression exponent. 
Although Asselman [2000] argued that parameters $a$ and $b$ of the sediment rating curve have no particular physical significance, other studies regard the $a$ coefficient as an index of erosion severity in the river channel $[55,56]$. Typically, $a$ displays high values in areas comprising easily erodible and displaceable rocks. The $b$ exponent is employed to describe the erosive power of the stream. High values indicate a strong increase in the sediment removal and transport capacity as the flow discharge increases. Moreover, the $b$ exponent can also reflect the extent to which new sediment sources become available as the flow discharge rises [21].

Therefore, the $b$ exponent of the regression represents the sediment concentration per discharge unit and its value depends on the availability of source areas which provide sediments to the channel. Consequently, it is also closely related to soil erodibility and the amount of fine-grained sediment reaching the stream channel $[21,56]$. The $b$ exponent indicates the rate of change of the suspended sediment load with the variation of the flow discharge, thus, depending on its value, the following situations are possible [25]: (i) When $b=1$, the suspended sediment load increases linearly with the rising flow discharge. The transport curve is a straight line; (ii) When $0<b<1$, the suspended solid load increases slower compared to the discharge. In this case, the rating curve has a concave shape. Rivers with such curves have limited material inputs, which indicates that the amount of transported alluvium is correlated with the availability of the source area to provide sediments [57]; (iii) When $b>1$, the suspended solid load increases faster than the flow discharge and the curve has a convex shape. The transport capacity documented for this type of curve is typically limited [21]. This situation occurs when the channel contains coarse-grained material [58] or the flow discharge has to reach a certain threshold in order to make the sediment available for suspended transport.

The values of the suspended sediment load estimated based on the rating curve and the $b$ exponent are often underestimated compared to the real values due to the fact that the projections of the flow discharge and the suspended sediment load have a high degree of dispersion, particularly during flood events as a result of the superimpression of external controls during periods with high flows.

The flow discharge is used as a surrogate for determining stream power, therefore some errors may occur in estimating the transport rate in situations with discrepancies between stream power and flow discharge [58].

The dispersion of points around the rating curve can be a result of the hysteresis effect generated by the time gap between the peaks of the sediment load and the flow discharge. In the case of a flood event, the relation between SSC and Q can be described as a loop, rather than a rating curve, since the sediment load differs on the rising limb of the flood compared to the falling limb $[22,25]$.

By relating the suspended sediment concentration to the flow discharges characteristic for rising and falling periods of the flood events, Williams [1989] proposed five main classes of hysteresis: (i) Type I-clockwise hysteresis is specific to situations where the peak suspended sediment concentration occurs before the peak discharge, indicating limited sediment sources within the channel or even sediment depletion. At the onset of the flood event the energy is sufficient for the removal of materials from the channel or its close proximity; (ii) Type II - counter clockwise hysteresis $(A C)$ is characteristic to situations where the suspended sediment concentration peaks after the peak discharge, indicating either a more remote source of alluvium, a flow discharge threshold which has to be reached in order to mobilize bank materials, or a precipitation threshold required for initiating erosion in the catchment; (iii) Type III - single-valued line, where both peaks (i.e. suspended sediment concentration and discharge) occur simultaneously, pointing to continuous sediment delivery. This type depends to a larger extent on the entrainment of channel material rather than the input from slopes; (iv) Type IV-figure eight combines the first two types. This hysteresis model is influenced by the presence of various sediment sources. In the initial stage of the flood event, the sediment originates in the channel or its close proximity. However, after the depletion of this source, a second phase of sediment concentration increase ensues due to the availability of other sources; (v) Type $V-$ complex. In some instances the relation between the suspended sediment load and the flow discharge is rather complex, with several hysteresis loops (clockwise, counter clockwise, single-valued), both 
on the rising limb, as well as the falling limb. This type of hysteresis typically occurs during flood events with large duration and several discharge peaks.

The hysteresis index $(\mathrm{HI})$ calculated at mid-point discharge $\left(\mathrm{Q}_{\mathrm{mid}}\right)$ is closely related to the hysteresis type. The plot of the hysteresis type reveals the dynamic response of the suspended sediment load to changes in the flow discharge during a flood event. In order to quantify the magnitude and direction of the hysteresis effect we calculated the hysteresis index using the following equation [59]:

$$
\mathrm{Q}_{\text {mid }}=\mathrm{k}\left(\mathrm{Q}_{\max }-\mathrm{Q}_{\min }\right)+\mathrm{Q}_{\min },
$$

where $\mathrm{Q}_{\text {mid }}\left(\mathrm{m}^{3} \mathrm{~s}^{-1}\right)$ is the mid-point discharge; ; $\mathrm{Q}_{\max }$ is the peak discharge; $\mathrm{Q}_{\min }$ is the starting discharge of the flood event, and $\mathrm{k}$ is the position where the loop width is evaluated relative to the flow discharge class $(k=0,5)$.

$$
\begin{gathered}
\mathrm{HI}_{\mathrm{mid}}=\left(\mathrm{Q}_{\mathrm{sRL}} / \mathrm{Q}_{\mathrm{sFL}}\right)-1 \text { (for type I of hysteresis), } \\
\mathrm{HI}_{\text {mid }}=\left[-1\left(\mathrm{Q}_{\mathrm{sRL}} / \mathrm{Q}_{\mathrm{sFL}}\right)\right]+1 \text { (for type II of hysteresis), }
\end{gathered}
$$

where HImid is the hysteresis index; $\mathrm{Q}_{\mathrm{sRL}}$ - value of the suspended sediment load corresponding to $\mathrm{Q}_{\mathrm{mid}}$ on the rising limb; $\mathrm{Q}_{\mathrm{sFL}}$ - value of the suspended sediment load corresponding to $\mathrm{Q}_{\mathrm{mid}}$ on the falling limb.

\section{Results}

\subsection{Types of flood events}

From 2000 to 2017, 77 flood events were recorded at the four gauging stations which reached or exceeded the bankfull discharge. According to their stream power, duration and amount of transported sediment, these events were ranked into four classes. Of the 77 analyzed events, $3(4 \%)$ pertained to type A; $12(16 \%)$ to type B; $11(14 \%)$ to type C, and $51(66 \%)$ to type D (Figure 2).
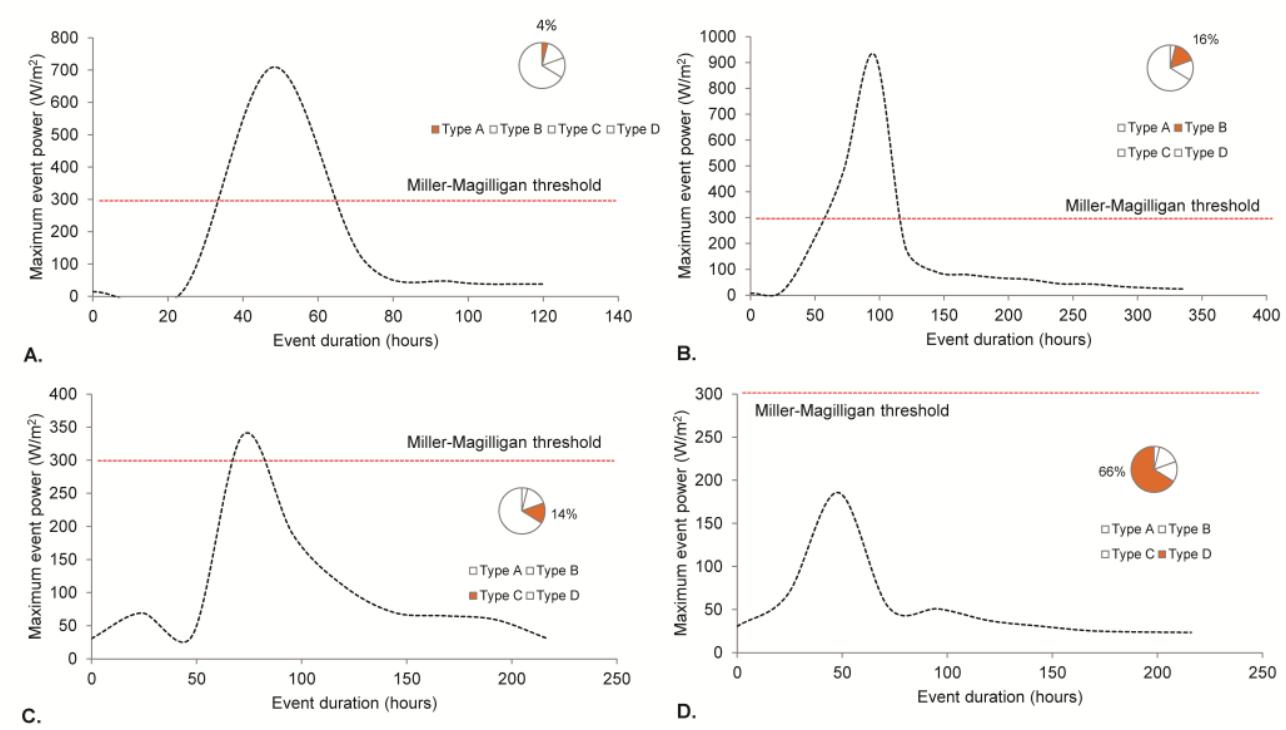

Figure 2. Types of flood events according to the maximum stream power and duration: A. Type A flood (Târgu Ocna - 26 - 31 July 2004); B. Type B flood (Vrânceni - 9 - 23 July 2005); C. Type C flood (Lunca de Sus - 9 - 18 July 2005); D. Type D flood (Goioasa - 22 - 31 March 2007). Pie charts show the number and percentages of the respective types of flood events. 
The investigated timeframe extended over a period of 6575 days, amounting to 157,800 hours. Overall, the period with flood events exceeding Qbf was 22,128 hours, corresponding to $14 \%$ of the analyzed interval, with the following particularities at each gauging station: Lunca de Sus - 14 flood events exceeded $\mathrm{Qbf}_{\mathrm{bf}}$ amounting to 3816 hours or $2.4 \%$ of the investigated period, during which was transported $52 \%$ ( 0.15 mil. $\mathrm{t}$ ) of the total sediment carried through this section; Goioasa -22 flood events exceeded Qbf, amounting to 6624 hours or $4.2 \%$ of the time, during which $74 \%$ (3.4 mil. t) of the total sediment was transported; Târgu Ocna - 20 floods surpassed Qbf, amounting to 5568 hours (3.5\% of the interval), during which was transported $50 \%$ ( 10 mil. $\mathrm{t}$ ) of the total sediment load; Vrânceni - 21 flood events exceeded Qbf, adding up to 6120 hours or $4 \%$ of the analyzed timeframe, during which $80 \%$ ( 28 mil. $\mathrm{t})$ of the total sediment was transported.

\subsection{Stream power}

The daily specific stream power was calculated at the four gauging stations using eq. (1), yielding the following results: (i) the average values of the specific stream power between 2000 and 2017 ranged from $10.4 \mathrm{Wm}^{-2}$ (at Vrânceni station) to $16.2 \mathrm{Wm}^{-2}$ (at Târgu Ocna station); (ii) the maximum values ranged between $345 \mathrm{Wm}^{-2}$ (at Lunca de Sus station, on June 2, 2016) and $1549 \mathrm{Wm}^{-2}$ (at Târgu Ocna station, on July 12, 2005); (iii) the time variation plots for the specific stream power at the four gauging stations (Figure 3) point out that the $\mathrm{D}_{50}$ threshold movement was exceeded in 16\% (i.e. 1040 days out of a total 6575 days) of the investigated timeframe at Lunca de Sus, compared to 11\% (725 days) at Goioasa, 9\% (581 days) at Târgu Ocna and 30\% (1940 days) at Vrânceni station; (iv) the $300 \mathrm{Wm}^{-2}$ threshold, above which major changes can occur in the channel bed, and implicitly significant sediment transport, was exceeded in less than $1 \%$ of the total investigated timeframe at all four gauging stations: at Lunca de Sus, the threshold was barely surpassed in $0.05 \%$ of the interval during the flood events of $2005-338 \mathrm{Wm}^{-2}, 2014-318 \mathrm{Wm}^{-2}$ and $2016-345 \mathrm{Wm}^{-2}$; at Goioasa the threshold was exceeded in $0.12 \%$ of the analyzed time, in $2004-829 \mathrm{Wm}^{-2}$, in 2005 - three times: 776 , 460 and $430 \mathrm{Wm}^{-2}$, in $2007-317 \mathrm{Wm}^{-2}$, in $2010-695 \mathrm{Wm}^{-2}$ and in $2016-567 \mathrm{Wm}^{-2}$; at Târgu Ocna the Magilligant threshold was surpassed in $0,12 \%$ of the analyzed period, with very high values on July 12, $2005\left(1549 \mathrm{Wm}^{-2}\right)$ and June 2, $2016\left(713 \mathrm{Wm}^{-2}\right)$; at Vrânceni the threshold was exceeded in $0.14 \%$ of the time (9 days) in 2004, $2005\left(930 \mathrm{Wm}^{-2}\right), 2010,2012$ and $2016\left(825 \mathrm{Wm}^{-2}\right)$.
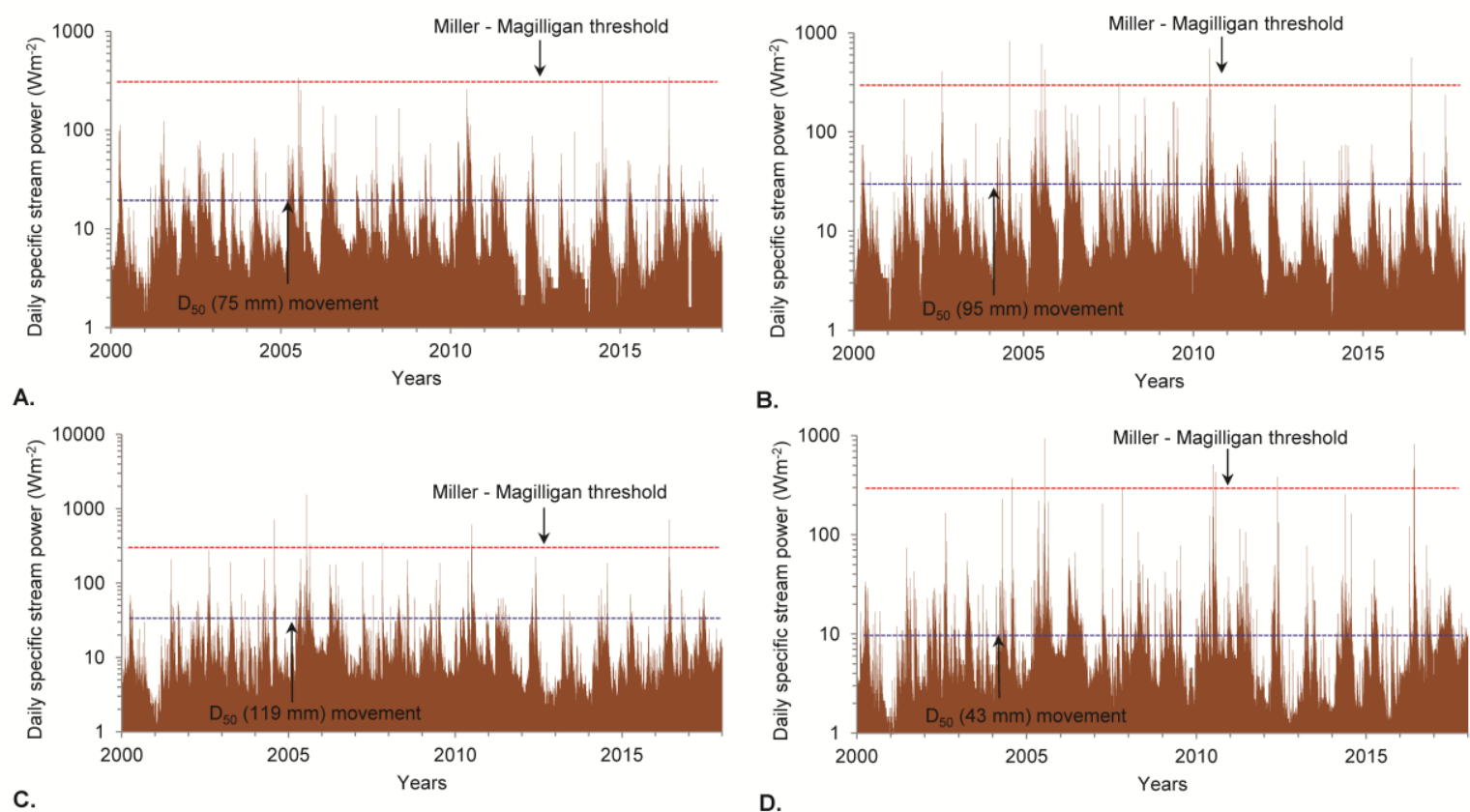

Figure 3. Daily specific stream power at station: A. Lunca de Sus; B. Goioasa; C. Târgu Ocna; D. Vrânceni. 


\subsection{Energy generated by the flood}

The total amount of energy expended during one year varies from 160 MJ (at Vrânceni station in 2013) and 1049 MJ (at Târgu Ocna in 2005), whereas the average ranges between 320 and 512 MJ (Table 2). The total energy generated during the flood events of 2005 and 2010 is ca. 4 times higher compared to the energy expended in 2013, the year with the lowest recorded value. Flood peaks may contribute in certain years (e.g., 2005, 2010 and 2016 at Vrânceni station) with more than 50\% of the total energy expended during one year. The average annual energy expenditure was 429 MJ between 2000 and 2017.

Table 2. Total energy expenditure over the duration of one year and during flood events

\begin{tabular}{|c|c|c|c|c|c|c|c|c|}
\hline \multirow{2}{*}{ Years } & \multicolumn{4}{|c|}{ Total energy expended per unit area (MJ) } & \multicolumn{4}{|c|}{ Total energy of floods (MJ) } \\
\hline & LS & GO & TO & VR & LS & GO & TO & VR \\
\hline 2000 & 270 & 309 & 267 & 161 & 83 & 0 & 0 & 0 \\
\hline 2001 & 374 & 369 & 342 & 185 & 46 & 59 & 54 & 0 \\
\hline 2002 & 509 & 676 & 594 & 311 & 62 & 165 & 145 & 68 \\
\hline 2003 & 318 & 381 & 396 & 233 & 0 & 0 & 37 & 0 \\
\hline 2004 & 316 & 540 & 566 & 329 & 0 & 128 & 163 & 122 \\
\hline 2005 & 520 & 963 & 1049 & 636 & 125 & 513 & 513 & 366 \\
\hline 2006 & 527 & 680 & 724 & 391 & 117 & 269 & 176 & 0 \\
\hline 2007 & 394 & 523 & 497 & 279 & 36 & 125 & 115 & 90 \\
\hline 2008 & 435 & 573 & 520 & 323 & 66 & 155 & 53 & 46 \\
\hline 2009 & 332 & 516 & 483 & 264 & 0 & 137 & 47 & 0 \\
\hline 2010 & 702 & 814 & 861 & 586 & 187 & 361 & 323 & 315 \\
\hline 2011 & 397 & 479 & 501 & 304 & 0 & 0 & 0 & 67 \\
\hline 2012 & 249 & 359 & 374 & 246 & 0 & 66 & 94 & 94 \\
\hline 2013 & 194 & 257 & 244 & 160 & 0 & 0 & 0 & 0 \\
\hline 2014 & 349 & 364 & 386 & 280 & 97 & 0 & 52 & 69 \\
\hline 2015 & 244 & 303 & 347 & 212 & 0 & 0 & 0 & 0 \\
\hline 2016 & 441 & 545 & 612 & 516 & 99 & 141 & 218 & 255 \\
\hline 2017 & 303 & 369 & 451 & 340 & 0 & 43 & 0 & 0 \\
\hline Mean & 382 & 501 & 512 & 320 & 51 & 120 & 111 & 83 \\
\hline
\end{tabular}

Depending on the total energy expended and the maximum annual specific stream power (at Vrânceni station, where the influences of the entire drainage basin are cumulated), three distinctive clusters of years were singled out in terms of hydro-geomorphology (Figure 4): (i) years with high flow discharge values, and consequently high stream power and energy expenditure $(2005,2010$, 2016), when the largest sediment transport rates were recorded; (ii) a second cluster including years (2004, 2007, 2012 and 2014) when the hydraulic parameters reached values close to the Miller-Magilligan threshold, and sediment transport had moderate values, and (iii) the last cluster, comprising the remaining years of the 2000 - 2017 interval, with typically low values for both energy parameters and sediment transport, and a certain degree of stability of the channel. 


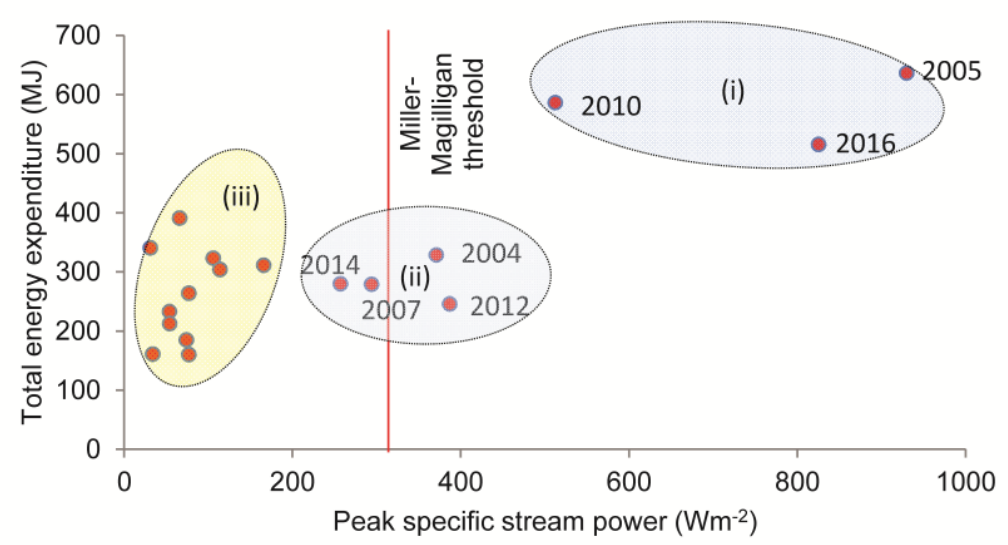

Figure 4. Distribution of hydrological years depending on the total energy expenditure and the maximum annual specific stream power (Vrânceni gauging station - 2000 to 2017).

\subsection{The hysteresis effect}

The analysis of the hysteresis effect for the 77 flood events recorded at the four gauging stations along Trotus, River led to the following results:
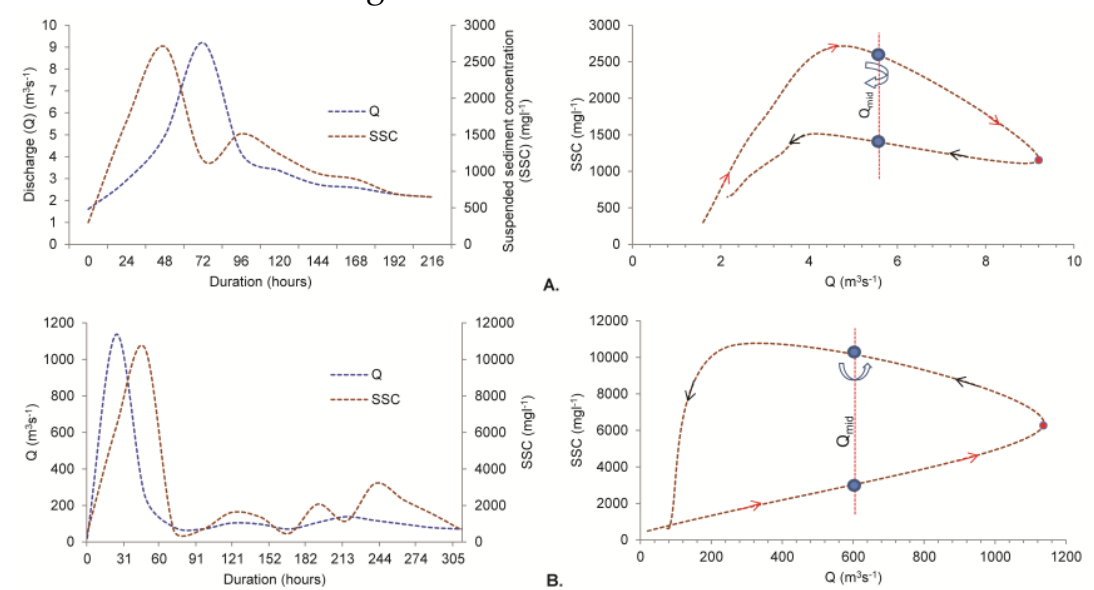

A.
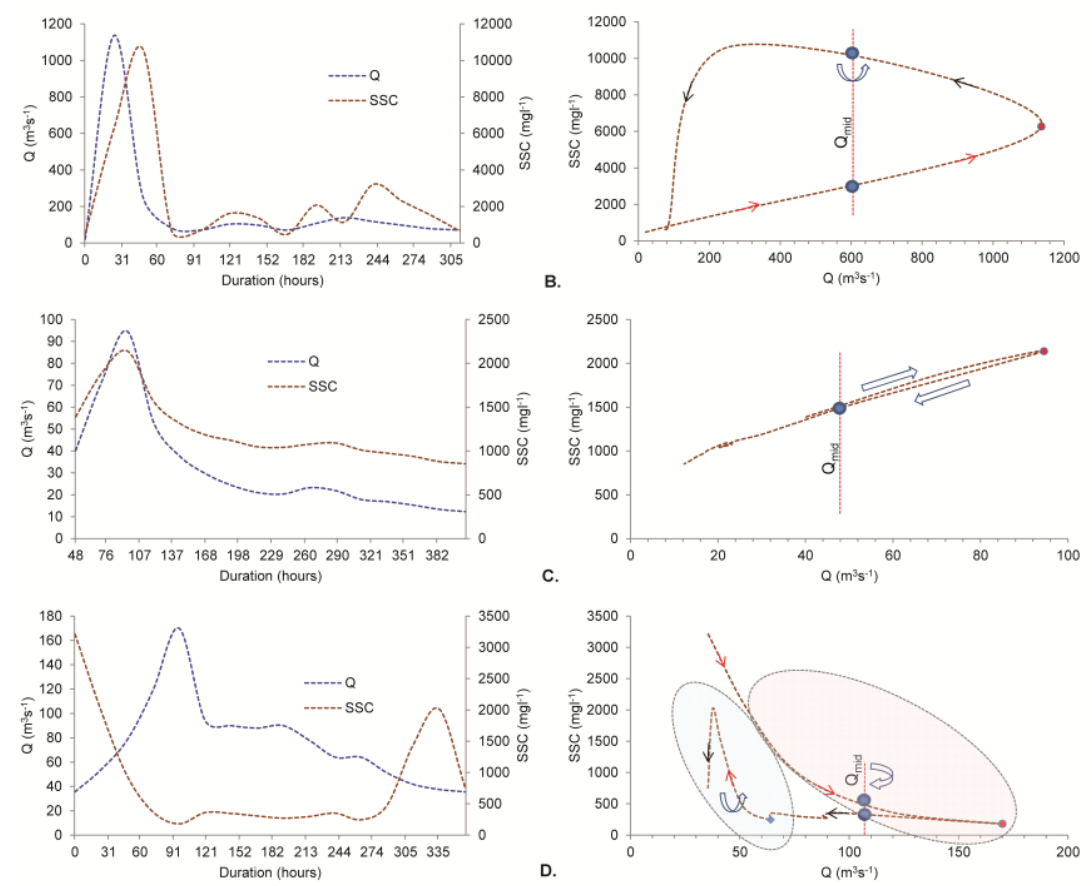

c.

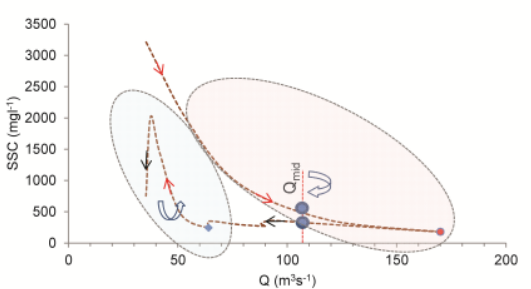

Figure 5. A. Type I hysteresis loop (positive or clockwise) - Lunca de Sus - 15-24 August 2002; B. Type II hysteresis loop (negative or counter clockwise) - Vrânceni - 27-31 July 2004; C. Type III hysteresis loop (single-valued line) - Goioasa - 19 May-12 June 2010; D. Type V hysteresis loop (complex) - Târgu Ocna -27 March-11 April 2006.

(i) at Lunca de Sus, of 14 investigated events, 9 (64\%) pertained to type I (Figure 5A) and 5 (36\%) to type II; (ii) from Goioasa section onward, complex hysteresis loops are present, indicating a 


\section{0 of 22}

diversification of sediment sources. Of the 22 analysed flood events, 14 (64\%) pertained to type I of hysteresis, 4 (14\%) to type II, 3 (14\%) were complex and just one event ranked as type III (5\%) (Figure 5C); (iii) at Târgu Ocna station, of 20 analysed flood events, 10 (50\%) ranked as type I, 4 (20\%) as type II, $3(15 \%)$ as type V (Figure 5D), whereas the remaining $3(15 \%)$ pertained to type III; (iv) positive hysteresis is prevalent in the case of flood events analysed at Vrânceni gauging station. Of the 21 studied events, 12 (57\%) ranked as type I, 5 (24\%) as type II (Figure 5B), and 4 (19\%) as type V.

\subsection{Estimates of bedload sediment transport rate}

The average rate of bedload sediment transport for the entire Trotuş River is $234 \mathrm{t}$. However, there significant variations between the four gauging stations: at Lunca de Sus, the average rate was 5.6 t, at Goioasa - 84 t, at Târgu Ocna - 323 t, while at Vrânceni the rate was 525 t. During flood events, bedload sediment transport rates exceed the average values several hundreds of times (Figure 6). For example, during the peak discharge of 12-13 July 2005, the estimated transport rate was 37,840 $\mathrm{t}$ at Goioasa station, 265,656 $\mathrm{t}$ at Târgu Ocna, and ca. 200,000 t at Vrânceni station. At Lunca de Sus station the maximum transport rate was estimated for 2 July 2016, amounting to ca. 2200 t. By relating these data to the suspended sediment load, it was established that the bedload accounts for ca. $15 \%$ at Lunca de Sus and $11 \%$ at Vrânceni.

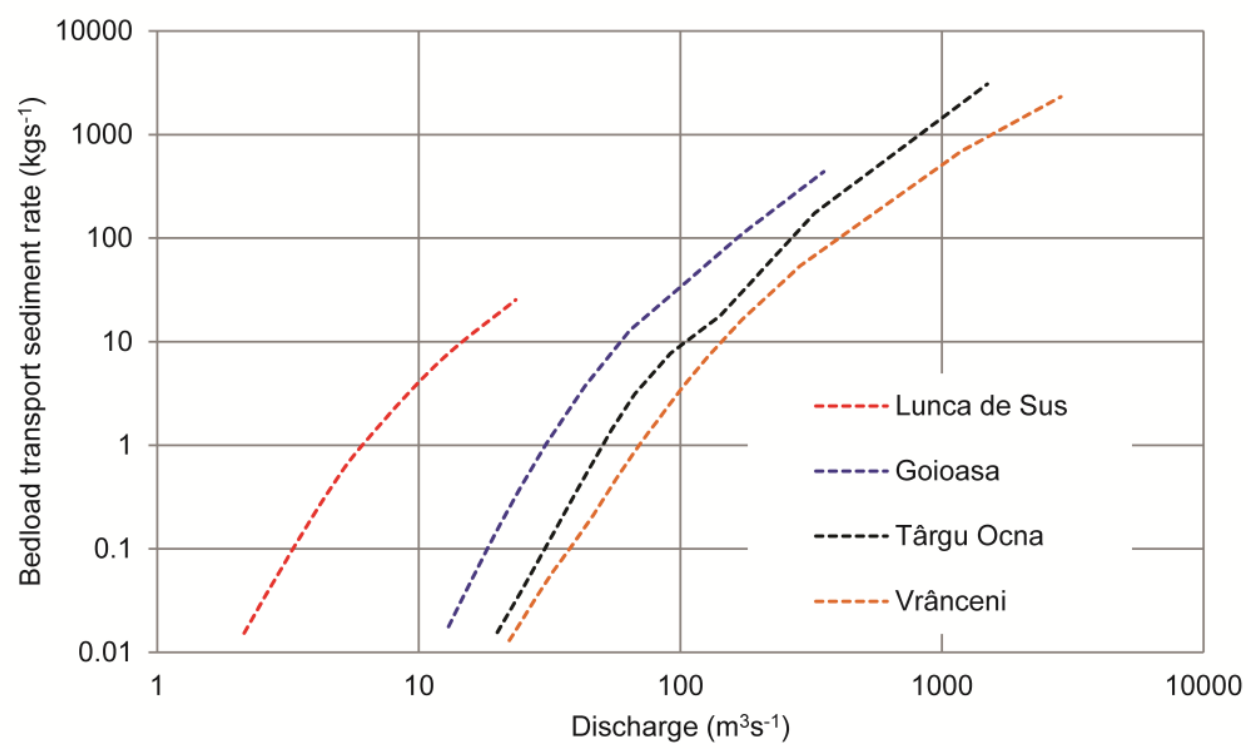

Figure 6. Bedload transport rate estimated using BAGS software.

\section{Discussion}

\subsection{Suspended sediment transport in relation to the flow discharge}

\subsubsection{Suspended sediment rating curve}

In the section focusing on the suspended sediment rating curve the analysis was performed on three distinct intervals of the 2000-2017 timeframe: 2000-2005, 2006-2010 and 2011-2017, delineated based on major flood events. The highest values of the suspended sediment load were recorded when $Q_{b f}$ was exceeded (Figure 7). The values of the $b$ exponent are above 1 in all the cases (ranging between 1.79 and 3.07), which reflects the size of bed material, indicating a gravel-bed channel [34].

For several rivers were observed changes throughout time of the $a$ coefficient and the $b$ exponent $[60,61,62,63,64]$. These variations point towards an alteration of erodibility and/or material inputs in catchments, or in the erosion and transport capacity of the river [21]. The multiannual variability of the rating curve is often influenced by certain climatic trends, by channel bed adjustments as a result of extreme events, or as a consequence of anthropogenic interventions in the 
drainage basin [65]. High values of this exponent (>1.6) indicate an increase in sediment removal and transport within the river as the flow discharge rises. The vertical changes of the sediment rating curve can also be linked to the increasing discharge [61].
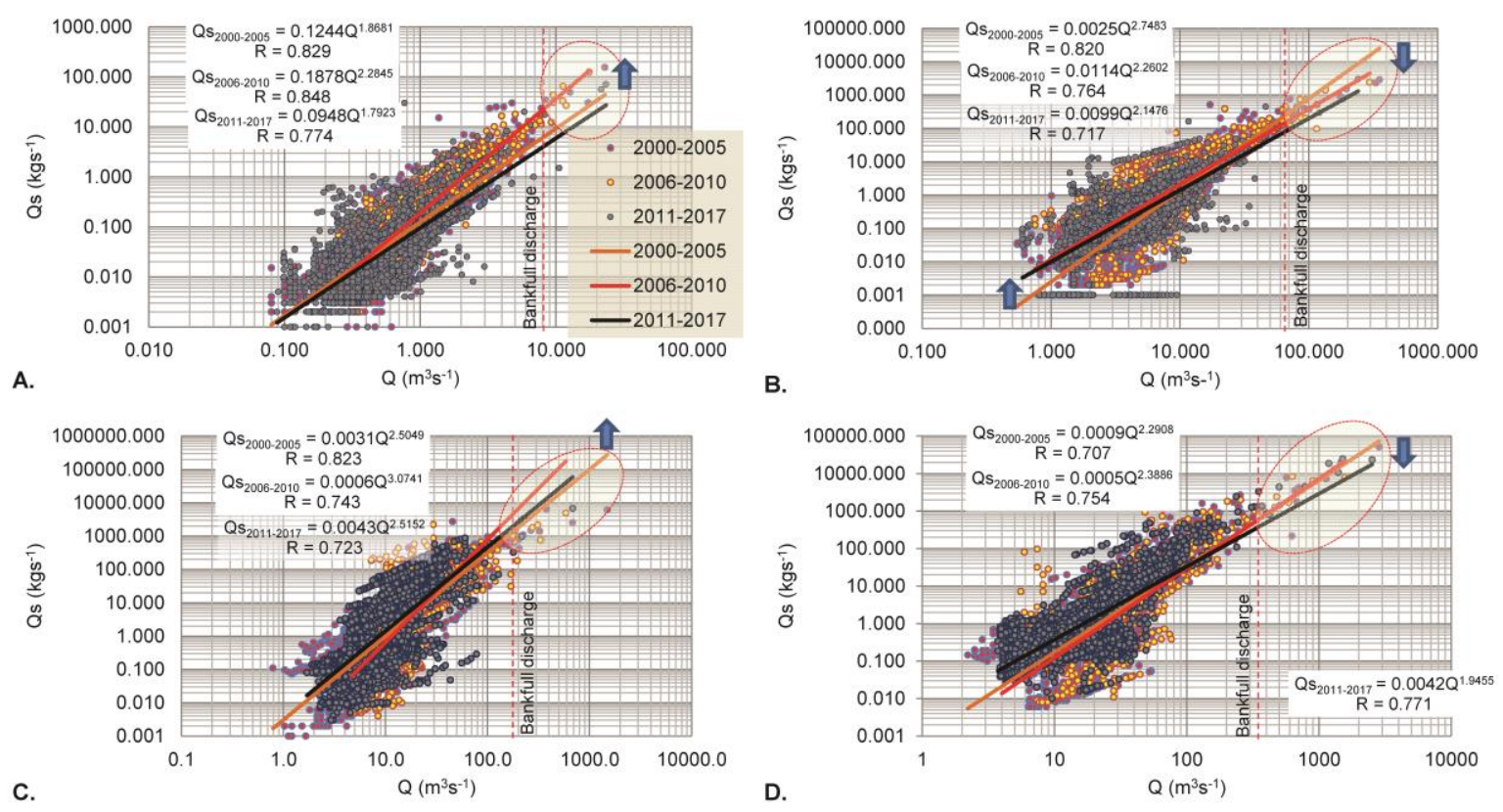

Figure 7. Temporal trend of sediment rating curves at gauging stations along Trotuș River: A. Lunca de Sus; B. Goioasa; C. Târgu Ocna; D. Vrânceni.

As regards the temporal changes of coefficients $a$ and $b$ and the vertical oscillations of the sediment rating curve, the following trends were observed at gauging stations along Trotuș River: ( $i$ ) after the major flood events of 2005, an increase of the $b$ exponent was documented at all gauging stations (with the exception of Goioasa), indicating a growing transport capacity of the river. However, after 2010, the $b$ exponent relapsed to a value similar to that prior to the flood events of 2005; (ii) along the mid-course of the river an increase of the $a$ coefficient was observed, as well as the decrease of the $b$ exponent, suggesting a growing sediment input, as well as a reduction in the transport capacity; (iii) at Lunca de Sus and Târgu Ocna (Figure 7 A, C) a positive vertical migration of the rating curve was documented between 2006 and 2010, mainly as a result of increasing flow discharges to an extent which could boost sediment removal and transport. The same situation, albeit less apparent, was also observed at Vrânceni station; (iv) in the mid-course (at Goioasa station) the sediment rating curve for the 2006-2010 interval was rotated clockwise, with the central point near the $Q_{b f}$. The suspended sediment transport at flow discharges above $Q_{b f}$ decreased slightly, whereas below this value an increase was documented.

The temporal and spatial changes of SRC shape prompted us to question which are the control factors for these changes. In this respect, the findings are divided. Some authors $[60,66]$ believe that basin-scale morphometric variables and hydro-climatic variables could influence the spatial-temporal changes of SRC coefficients. Others $[67,68,69]$ argue that channel-floodplain morphology is responsible to a larger degree for the changes of SRC shape. The interannual variability of SRC coefficients is often influenced by climate trends and channel recovery after flood events $[60,65]$. However, in the case of Trotus River, the consensus is that the changes occurring in the channel morphology (and consequently in sediment source availability) after the flood events of 2005 led to the modification of SRC coefficients. Thus, the changes in the sediment transport rates after the 2005 floods attest to the fact that these events mark major thresholds in the hydrogeomorphic evolution of river channels. Moreover, the situation characteristic for the 2011-2017 interval indicates that the general tendency is the return to the initial state. 


\subsubsection{Hysteresis loops}

The suspended sediment transport rate can be influenced by either energy conditions [70], or the sediment supply [21]. In order to infer the degree of availability of sediments within the channel or in the drainage basin the SSC-Q hysteresis patterns were employed. Based on these models, several characteristics of sediment transport processes can be interpreted [18]. By applying the SSC-Q models it was determined that on Trotus River more than $60 \%$ of hysteresis loops typical for type A (67\%), type C (60\%) and type D (61\%) flood events ranked as type I (clockwise). This situation appears to be prevalent in many rivers [71,72], and could be attributed to the appurtenance of their basins to a "supply-limited" sediment delivery system [73]. In this instance the sediment source area is located within the channel or in its close proximity [74]. In the case of type B flood events, type I hysteresis loops have diminished percentages (ca. 40\%), while types V (complex) (35\%) and II (counter clockwise) (25\%) increase. This indicates that during more than $60 \%$ of the manifestation time for this type of flood a connection is maintained with sediment sources from the catchment. Complex hysteresis loops occur in flood events characterized by several discharge peaks [75]. In such floods (e.g., 2004, 2005, 2010 and 2016, all type B), with large duration and several peaks, a shift was documented in hysteresis loops, depending on the source areas, thus generating a complex model. Martin et al. (2014) [76] show that these hysteresis pattern changes can be attributed to one of two scenarios: (i) either a shift occurs from easily erodible channel material to more cohesive bed or bank material, or (ii) a transition from the channel and its proximal source area to the slopes. Type II hysteresis loops account for a significant share of the total number of D type floods (25\% or 13 flood events), therefore confirming that this type is specific to moderate floods with limited flow discharge, low sediment yield and high SSC [73,75,77]. The prevalence of type I hysteresis loops is in full compliance with recent channel changes observed on Trotuş River, namely the tendency of degradation [33,34].

As regards the hysteresis index ( $\mathrm{HI}$ mid), $77 \%$ of all values were positive, which would support the relevance of the channel as a sediment source. The highest positive HImid was recorded during the 22 June-1 July flood event at Vrânceni station (+8.00). During this flood, at $\mathrm{Q}_{\text {mid }}$ of $172 \mathrm{~m}^{3} \mathrm{~s}^{-1}$, the suspended sediment concentration on the rising limb was as high as $2095 \mathrm{mgl}^{-1}$, whereas on the falling limb it amounted to just $233 \mathrm{mgl}^{-1}$. The lowest values of $\mathrm{HI}$ mid were recorded primarily at Târgu Ocna station (2005c, 2006b, 2010c, 2012 flood events), suggesting a continuos sediment supply in the mid-course, which is also supported by the relatively even suspended sediment concentrations on both the rising and falling limbs. The maximum negative $\mathrm{HI}$ mid was documented during the 9 July - 30 July 2005 flood event at Târgu Ocna (-1.46) and was generated by the fact that, at $Q_{\text {mid }}$ of $752 \mathrm{~m}^{3} \mathrm{~s}^{-1}$, the suspended sediment concentration was $3723 \mathrm{mgl}^{-1}$ on the rising limb, and nearly 2.5 times as high on the falling limb $\left(9175 \mathrm{mgl}^{-1}\right)$.

In terms of the average sediment load corresponding to the mid-point discharge $\left(Q_{\mathrm{mid}}\right)$ on both limbs of the hysteresis loop, the following situation was observed: at Lunca de Sus the average sediment load corresponding to the mid-point discharge (the average mid-point discharge between 2000 and 2017 was 7,9 ms $\mathrm{s}^{-1}$ ) was $24.7 \mathrm{kgs}^{-1}$ on the rising limb, and $17.5 \mathrm{kgs}^{-1}$ on the falling limb; at Goioasa (average $Q_{\text {mid }}-71 \mathrm{~m}^{3} \mathrm{~s}^{-1}$ ), the sediment load was ca. $437 \mathrm{kgs}^{-1}$ on the rising limb and $302 \mathrm{kgs}^{-1}$ on the falling limb; at Târgu Ocna (average $Q_{\text {mid }}-194 \mathrm{~m}^{3} \mathrm{~s}^{-1}$ ) the situation is reversed, with $1007 \mathrm{kgs}^{-1}$ of sediment transported on the rising limb compared to $857 \mathrm{kgs}^{-1}$ on the falling limb. This conjuncture is due to the extremely high value $\left(6900 \mathrm{kgs}^{-1}\right)$ of the suspended sediment load on the falling limb of the 9-30 July 2005 flood event, contrary to the general rule stating that the amount of transported alluvium is greater on the rising limb; and at Vrânceni station (average Qmid $=480 \mathrm{~m}^{3} \mathrm{~s}^{-1}$ ) the scale is also tipped in favour of the falling limb (an average of $4280 \mathrm{kgs}^{-1}$, compared to $3872 \mathrm{kgs}^{-1}$ on the rising limb), as a result of the large amount of sediment transported on the falling limb during the flood event of June 2006. During this flood, at $Q_{\text {mid }}$ of $1302 \mathrm{~m}^{3} \mathrm{~s}^{-1}$, the sediment load was ca. 24,000 $\mathrm{kgs}^{-1}$ on the falling limb and just ca. $12,000 \mathrm{kgs}^{-1}$ on the rising limb.

The analysis of the suspended sediment yield corresponding to the two opposing limbs of hysteresis loops led to the following results: (i) at Lunca de Sus station $48 \%$ of the total sediment yield 
(248,550 t) generated between 2000 and 2017 was transported during the 14 analysed flood events, of which $60 \%$ pertains to the rising limbs of hysteresis loops; (ii) at Goioasa, flood events accounted for $70 \%$ of the total suspended sediment yield (4,026 $232 \mathrm{t}$ ), with the same percentage corresponding to the rising limb; (iii) at Târgu Ocna the total suspended sediment yield throughout the investigated period was 17,578 $644 \mathrm{t}$, of which $45 \%$ was generated by the 20 analysed flood events. Furthermore, of the amount of suspended sediment yielded by floods, 55\% pertains to the rising limbs; (iv) at Vrânceni station, the 21 analysed floods account for approx. $80 \%$ of the total suspended sediment yield $(31,106360 \mathrm{t})$, with $77 \%$ corresponding to the rising limb. This situation further suggests that, overall, Trotus River channel represents the main source of sediment.

Regarding the relation between suspended sediment transport and the mid-point discharge of hysteresis loops, the correlation is rather strong, particularly on the rising limbs (Figure 8). In the cases of the two largest flood events in terms of the suspended sediment transport, both were type B floods, as recorded at Vrânceni station on 13 July 2005 and 12 June 2006, and revealed much higher transport rates on the falling limbs. This result indicates that during major floods the role of the catchment as a sediment source greatly increases. In the case of type D flood events, the amount of sediment corresponding to $\mathrm{Q}_{\mathrm{mid}}$ was higher on the falling limb in just $15 \%$ of instances, supporting the idea that for this flood type the main source area for sediment is the channel.

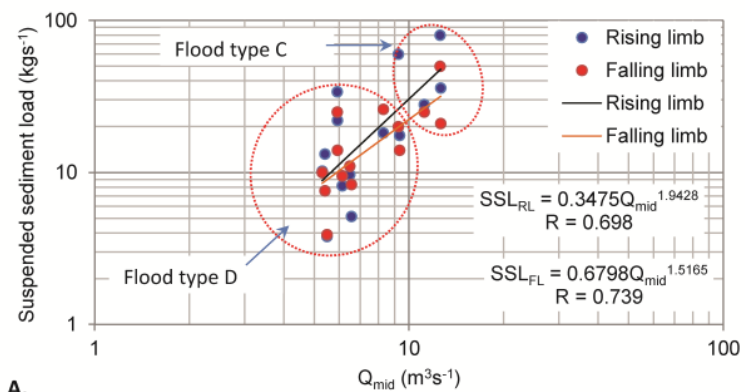

A.

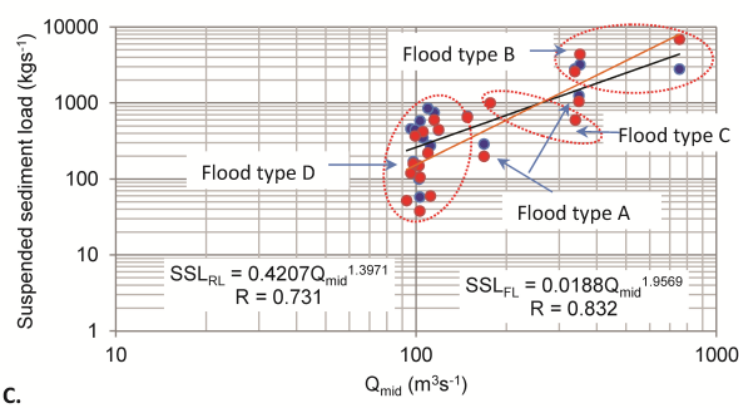

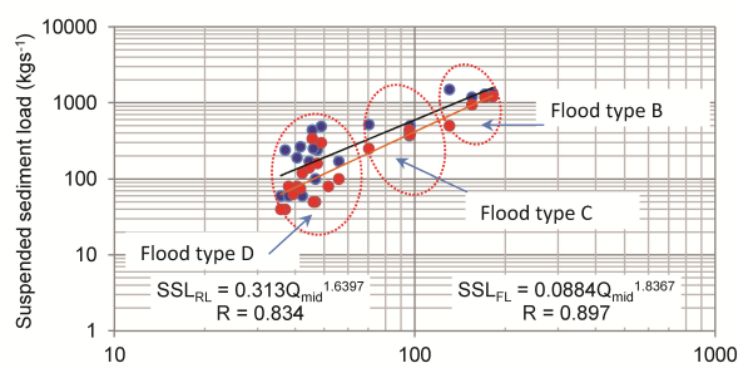

B.

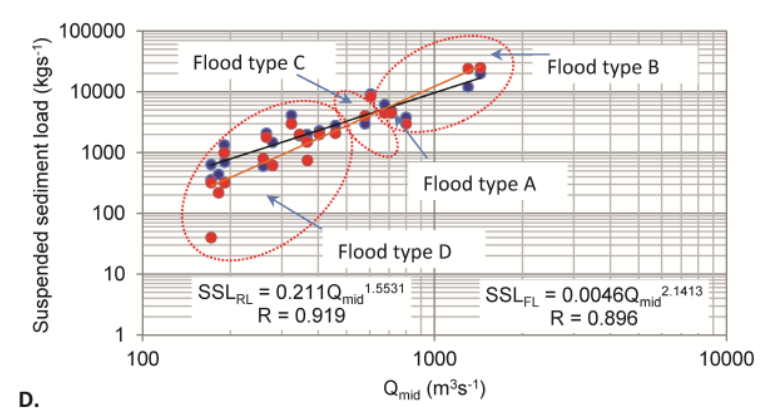

Figure 8. Relationship between the suspended sediment load and the mid-point discharge of the hysteresis loop. A. Lunca de Sus; B. Goioasa; C. Târgu Ocna; D. Vrânceni.

\subsection{Sediment transport in relation to stream power}

Results confirm that the stream power of a flood event can account for over $70 \%$ of the variability in the sediment yield generated by the event [50]. In the case of Trotus River, the highest sediment transport rates were also associated to high values of specific stream power (Figure 9). However, on rare occasions, stream power values close to the $300 \mathrm{Wm}^{-2}$ threshold can transport large amounts of sediment. The 2012 flood event at Vrânceni station is illustrative in this regard, with higher peak values for the sediment load at lower stream power compared to the 2010 flood. Another explanation could reside in the removal of vegetation from the active river channel during the 2010 flood event, which had not completely recovered by 2012, such that the nude areas of the channel during the 2012 flood event were greater compared to 2010, thus yielding more sediment. 
14 of 22

This situation is similar to the one presented by Milan (2012) [78], who stated that major floods have the additional role of creating a relaxation phase during which large amounts of sediments are redistributed within the channel by smaller floods. The response time necessary for the channel to reach a stable morphology is directly influenced by the vegetation recovery rate, which will increase the degree of stability of the banks and neighboring areas $[79,80]$. However, in reality the controls conditioning the variability of the solid load for each flood event are much more numerous and complex [11].
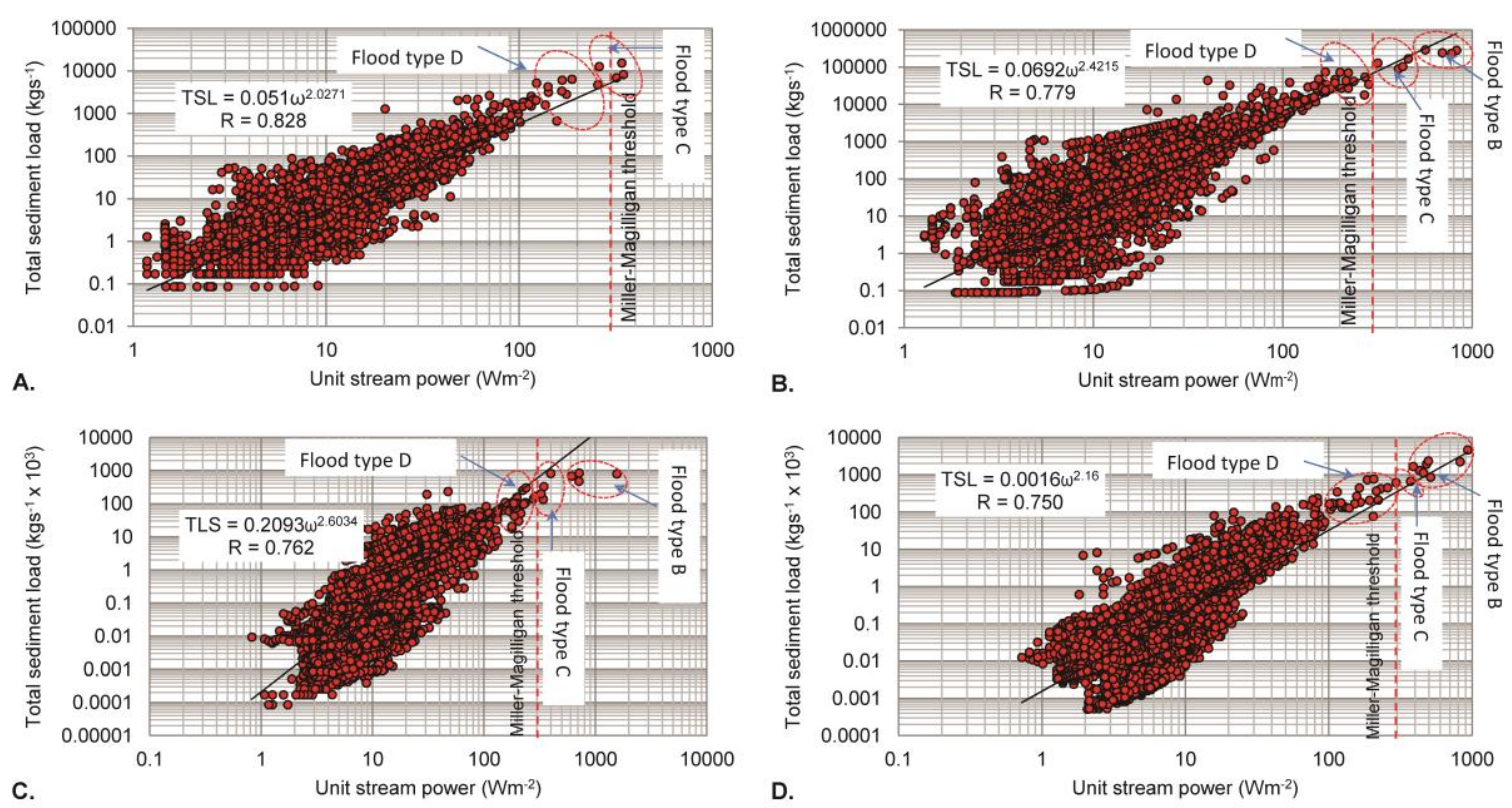

Figure 9. Relationship between the daily specific stream power and the daily sediment transport rate between 2000 and 2017 at: A. Lunca de Sus; B. Goioasa; C. Târgu Ocna; D. Vrânceni.

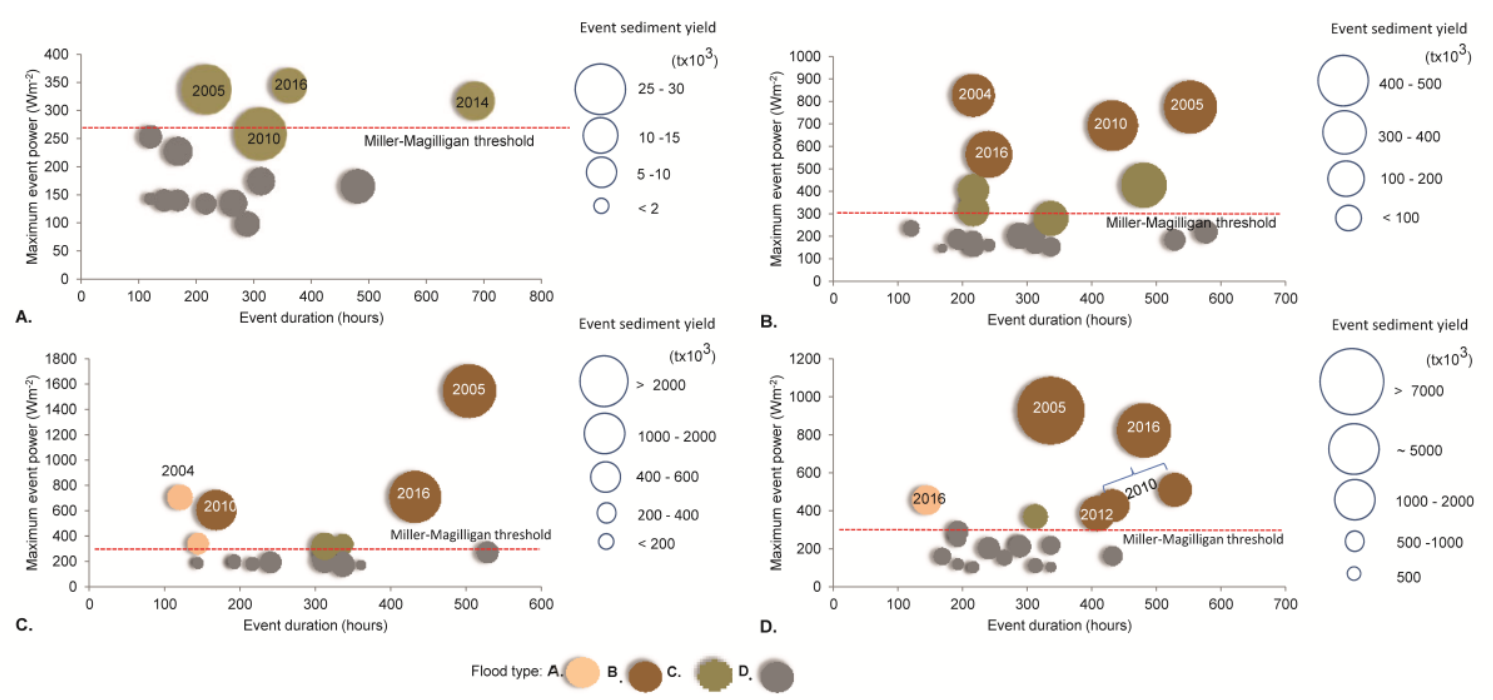

Figure 10. Suspended sediment transport related to the maximum stream power and flood event duration (circle size is related to the total amount of sediment) at: A. Lunca de Sus; B. Goioasa; C. Târgu Ocna; D. Vrânceni.

Depending on the maximum stream power and the duration of flood events, the suspended sediment transport had the following particularities between 2000 and 2017 (Figure 10): (i) during type A flood events (which accounted for ca. $0.26 \%$ of the 2000-2017 timeframe) $6 \%$ of the total 
15 of 22

sediment carried by floods was transported, amounting to ca. 41 mil. t; (ii) type B flood events (3\% of the analyzed timeframe) transported approx. $61 \%$ of the total alluvium carried through the gauging stations; (iii) type C flood events (2.5\% of the investigated interval) accounted for ca. $7 \%$ of the total sediment; (iv) type D floods (26\% of the time) contributed approx. $26 \%$ to the total sediment.

The data reveal that the largest amounts of sediment were transported during flood events characterized by both high magnitude and large duration. Albeit, in many instances the duration appears to be more relevant compared to the magnitude of the flood event in terms of the sediment load transported by the river or the changes occurring in the stream channel $[33,49,81]$. In the case of Trotuș River, some large duration, lower magnitude floods (2002, 2004, 2007, 2010 and 2014) were able to remove and carry significant amounts of sediment, which would suggest that under certain conditions, the duration of the event becomes very relevant. The literature comprises two currents of opinion on this matter. The first one supports the idea that the type of the precedent flood (in terms of magnitude and duration) has a significant influence on sediment transport. As such, if large magnitude events are preceded by smaller scale events, sediment transport is largely unaffected by them. However, if long duration, small magnitude flood events are preceded by high magnitude events, the decrease documented in the amount of transported sediment (40-70\%) is significant [82]. The second current points out that there is no memory effect of antecedent flood events, instead sediment composition is the major factor of fluvial system memory [83,84]. The majority of these conclusions are drawn based on lab experiments, whereas in nature the cumulated effects of several control factors can annul the influence of antecedent floods, as was the case with the 2007 flood events on Trotuş River.

A good correlation was determined between the maximum stream power during a flood event and the sediment yield generated by that event (Figure 11). Of the 41 mil. $t$ of sediment carried through the four sections during 77 flood events comprised in this study, ca. 30 mil. $t$ (74\%) were transported at stream power values above $300 \mathrm{Wm}^{-2}$.

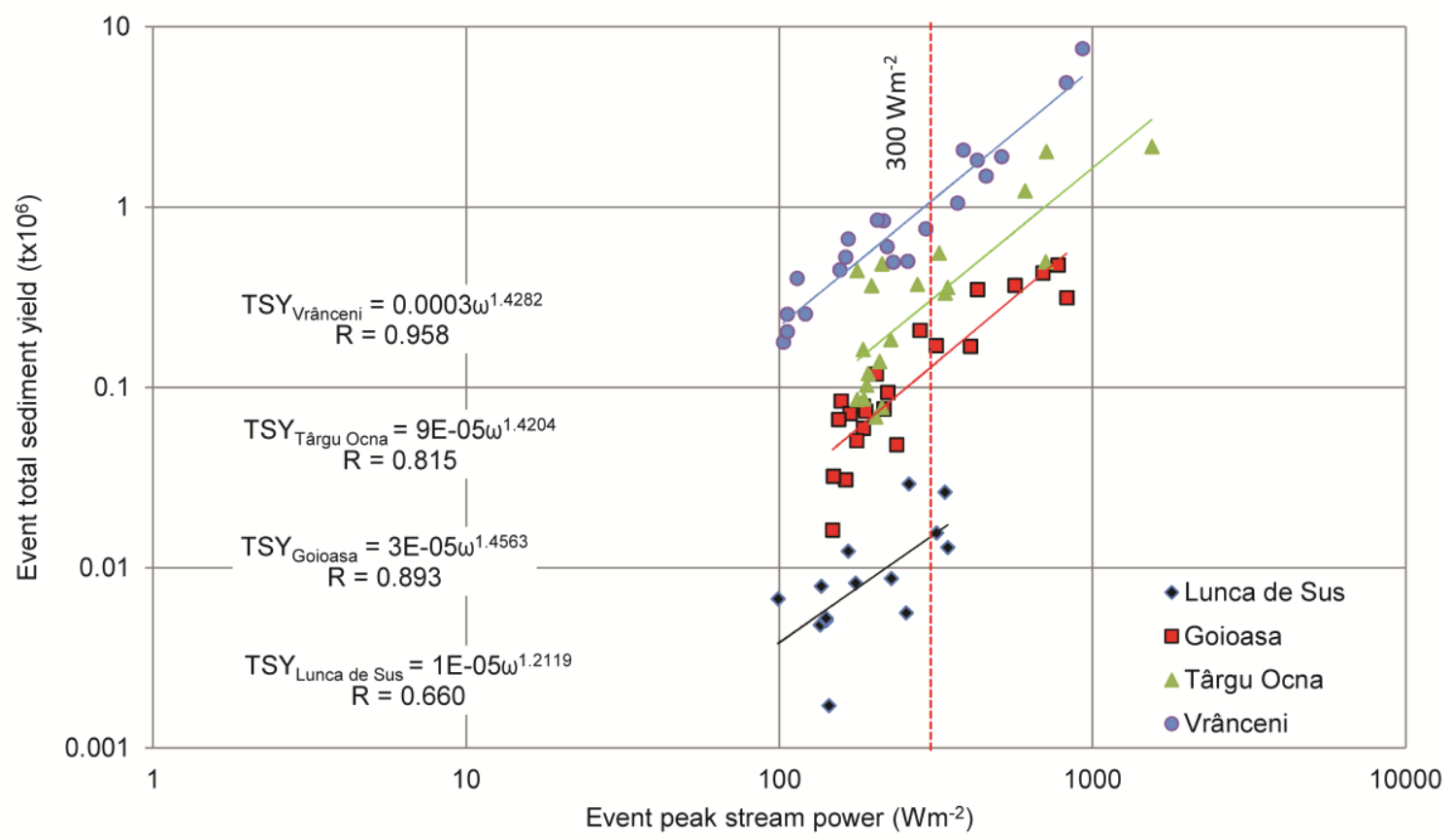

Figure 11. Relationship between the total sediment yield and the maximum stream power. 
16 of 22

The ratio between the sediment load and the stream power is defined as the maximum flow efficiency (MFE) [85,86]. According to this approach, an effective fluvial system can transport a large amount of sediment by using lower stream power. In order to determine this parameter, we calculated the ratio between the total annual sediment load and the average annual stream power at each gauging station [87]. The 0.65 value was used as the exponent of the stream power. In the years with type $B$, and occasionally type $C$ flood events (i.e. characterized by values of the stream power close to the $300 \mathrm{Wm}^{-2}$ threshold), the sediment flux was much higher compared to the multiannual average value (Figure 12A). The flood events of 2005, 2010 and 2016 are included in this category. Along Trotuş River a trend of increasing MFE was documented, which has been linked to a growing influx of sediment downstream (Figure 12B). Therefore, the lower course of Trotus River can be regarded as an effective fluvial system due to its capacity to transport sediments by using lower values of the stream power.
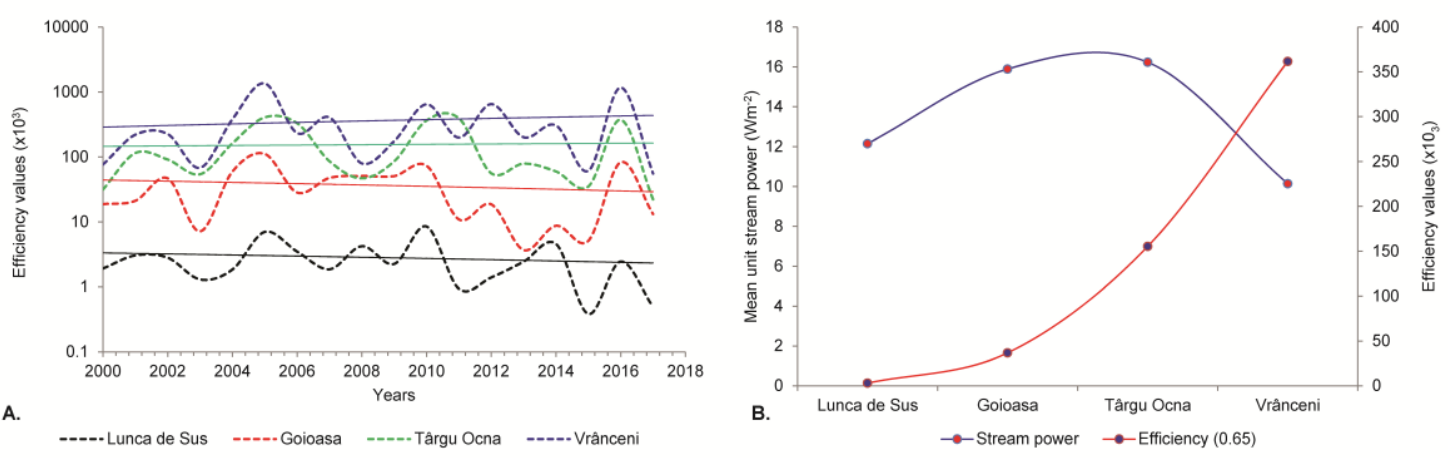

Figure 12. A. Annual variability of maximum flow efficiency (MFE); B. Downstream variability of MFE and stream power distribution along Trotuș River.

\subsection{Sediment transport in relation to the energy expenditure}

The relation between the sediment yield and the total energy expenditure reveals that typically the years with high values of specific stream power and implicitly of the energy expenditure are also characterized by high sediment transport rates [31]. In the case of Trotuş River, the total energy expended during a flood event can account for more than $80 \%$ of the sediment yield variability of that event (Figure 13).

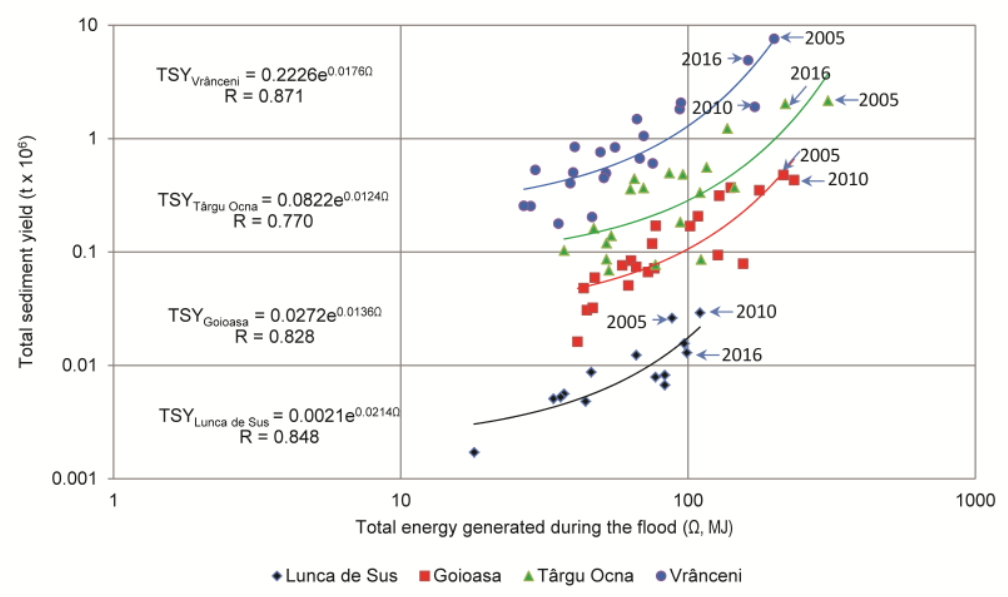

Figure 13. Exponential relationship between the suspended sediment yield and the total energy expenditure during flood events. 
As expected, the highest values of the sediment transport were documented in the years with major flood events (2005, 2010 and 2016) which generated large amounts of energy capable of displacing alluvium. However, the relation between the sediment yield and the energy expenditure during the flood event is conditioned by the availability of alluvium sources. For instance, during the flood event of June 2016, the energy expenditure determined at Târgu Ocna gauging station was ca. $220 \mathrm{MJ}$, and the sediment yield of this event amounted to approx. 2 mil. $t$, whereas a Vrânceni the sediment yield was ca. 2.5 times larger $(\sim 5$ mil. $t)$, albeit the energy expenditure was no higher than $160 \mathrm{MJ}$.

\section{Conclusions}

The estimation of the relations established between sediment transport and various hydrological and hydraulic characteristics of flood events required the usage of daily flow discharge and daily suspended sediment load data recorded at four gauging stations along Trotuș River. The bedload transport rate was evaluated using the Bedload Assessment for Gravel-bed Streams (BAGS) software. The average bedload transport rate for the entire length of Trotuş River was estimated at ca. $234 \mathrm{t}$, with significant variations between the four gauging stations (i.e. $5.6 \mathrm{t}$ at Lunca de Sus compared to $525 \mathrm{t}$ at Vrânceni). During flood events, bedload transport rates reach values several hundred times greater than the average rate. During the 2000 to 2017 period, 77 flood events were distinguished at the four gauging stations which exceeded the bankfull discharge. These events were ranked according to the classification introduced by Costa and O'Connor (1995) and adapted to sediment transport by Sear (2003). Based on this ranking, of the 77 analyzed events, 3 pertained to type $\mathrm{A}, 12$ to type $\mathrm{B}, 11$ to type $\mathrm{C}$, and the remaining 51 to type $\mathrm{D}$.

The relationship between sediment load and flow discharge were analyzed based on two approaches: the sediment rating curve (SRC) and the hysteresis effect. In order to capture the temporal changes of $a$ and $b$ coefficients and the vertical oscillations of the sediment rating curve, this analysis was performed on three distinct intervals of the 2000-2017 timeframe: 2000-2005, 2006-2010 and 2011-2017, delineated based on major flood events. The investigation revealed that after the major flood events of 2005 an increase of the $b$ exponent was documented at all gauging stations (with the exception of Goioasa), which indicates an augmented transport capacity of the river. However, after 2010 the $b$ exponent relapsed to a value similar to that prior to the flood events of 2005. As regards the study of hysteresis loops, we determined that more than $60 \%$ of type A, C and D flood events pertained to type I (clockwise hysteresis loops). In this case, the source area for sediments is located within the channel or in its close proximity. In the case of type B floods, type I hysteresis loops diminish their share to approx. 40\%, while types V (complex) (35\%) and II (counter clockwise) (25\%) are more frequent. This suggests that during more than $60 \%$ of the manifestation time for this type of flood a connection is maintained with sediment sources from the catchment.

The stream power during a flood event can account for over $70 \%$ of the variability in the sediment yield generated by the event. Of the 41 mil. $t$ of sediment carried through the four sections during 77 flood events comprised in this study, ca. 30 mil. $t$ (74\%) were transported at stream power values above $300 \mathrm{Wm}^{-2}$.

The relationship between the sediment yield and the total energy expenditure reveals that, as a general rule, the years with high values of specific stream power, as well as of the energy expenditure, also have typically large sediment transport rates, such that the energy expended during a flood event can account for more than $80 \%$ of the sediment yield variability of that event.

The changes documented in terms of the sediment transport rates after the flood events of 2005 show that major events mark important thresholds in the hydrogeomorphic evolution of river channels, albeit the general tendency manifested between 2011 and 2017 points to a recovery of the initial state. 


\section{8 of 22}

Supplementary Materials: The following are available online at www.mdpi.com/xxx/s1,Table S1: Classification of flood events based on duration and some energy parameters, Table S2: Data regarding the flow discharge, suspended sediment load, bedload, and sediment yield for each flood event, Table S3: Total sediment yield at Qmid for rising limb and falling limb, hysteresis index (HI) and hysteresis pattern for all flood events.

Author Contributions: This paper was the sole work of the author.

Funding: This research received no external funding.

Acknowledgments: This research was partially supported by the Geography Department of the Faculty of Geography and Geology and by CNCSIS-UEFISCSU, project PNII-IDEI number 436/2007.

Conflicts of Interest: The author declares no conflict of interest.

\section{References}

1. Zhu, Y.M.; Lu, X.X.; Zhou, Y. Sediment flux sensitivity to climate change: A case study in the Longchuanjiang catchment of the upper Yangtze River, China. Glob. Planet. Chang. 2008, 60, 429-442.

2. Fang, H.Y.; Cai, Q.G.; Chen, H.; Li, Q.Y. Temporal changes in suspended sediment transport in a gullied loess basin: The lower Chabagou Creek on the Loess Plateau in China. Earth Surf. Process. Landf. 2008, 33, 1977-1992.

3. Fan, X.; Shi, C.; Shao, W.; Zhou, Y. The suspended sediment dynamics in the Inner-Mongolia reaches of the upper Yellow River. Catena 2013, 109, 72-82.

4. Bussi, G.; Dadson, S.J.; Prudhomme, C.; Whitehead, P.G. Modelling the future impacts of climate and land-use change on suspended sediment transport in the River Thames (UK). J. Hydrol. 2016, 542, 357-372.

5. Walling, D.E. The Impact of Global Change on Erosion and Sediment Transport by Rivers: Current Progress and Future Challenges; The United Nations World Water Development Report 3; UNESCO: Paris, France, 2009; p. 26.

6. Vercruysse, K.; Grabowski, R.C.; Rickson, R.J. Suspended sediment transport dynamics in rivers: multi-scale drivers of temporal variation. Earth-Sci. Rev. 2017, 166, 38-52.

7. Kijowska-Strugała M. Sediment variability in a small catchment of the Polish Western Carpathians during transition from centrally planned to free-market economics. Geomorphology 2019, 325, 119-129.

8. Zhao, Y.; Cao, W.; Hu, C.; Wang, Y.; Wang, Z.; Zhang, X.; Zhu, B.; Cheng, C.; Yin, X.; Bing Liu, B.; Xie, G. Analysis of changes in characteristics of flood and sediment yield in typical basins of the Yellow River under extreme rainfall events. Catena 2019, 177, 31-40.

9. Markus, M.; Demissie, M. Predictability of annual sediment loads based on flood events. Jour. Hydraul. Eng. 2006, 11, 354-361.

10. Quesada, S.; Tena, A.; Guillén, D.; Ginebreda, A.; Vericat, D.; Martínez, E.; Navarro-Ortega, A.; Batalla, R.J.; Barceló, D. Dynamics of suspended sediment borne persistent organic pollutants in a large regulated Mediterranean river (Ebro, NE Spain). Sci. Total Environ. 2014, 473-474, 381-390.

11. Turowski, J.M.; Rickenmann, D.; Dadson, S.J. The partitioning of the total sediment load of a river into suspended load and bedload: A review of empirical data. Sedimentology 2010, 57, 1126-1146.

12. Joshi, S.; Xu, Y.J. Bedload and suspended load transport in the $140-\mathrm{km}$ reach downstream of the Mississippi River avulsion to the Atchafalaya River. Water 2017, 9, 716.

13. Fuller, I.; Passmore, D.; Heritage, G.; Large, A.; Milan, D.; Brewer, P. Annual sediment budgets in an unstable gravel-bed river: the River Coquet, northern England. Geol. Soc. 2002, Spec. Publ. 191 (1), 115-131. 


\section{9 of 22}

14. Joyce, H.M.; Hardy, R.J.; Warburton, J.; Large A.R.G. Sediment continuity through the upland sediment cascade: geomorphic response of an upland river to an extreme flood event. Geomorphology 2018, 317, 45-61.

15. Carling, P. The concept of dominant discharge applied to two gravel-bed streams in relation to channel stability thresholds. Earth Surf. Process. Landf. 1988, 13, 355-367.

16. Gomez, B. Bedload transport. Earth-Sci. Rev. 1991, 31, 89-132.

17. Pitlick, J.; Cui, Y.; Wilcock, P. Manual for Computing Bedload Transport Using BAGS (Bedload Assessment for Gravel-Bed Streams) Software; General Technical Report RMRS-GTR-223; U.S. Department of Agriculture, Forest Service, Rocky Mountain Research Station: Fort Collins, CO, USA, 2009.

18. Oeurng, C.; Sauvage, S.; Sánchez-Pérez, J.M.. Dynamics of suspended sediment transport and yield in a large agricultural catchment, southwest France. Earth Surf. Process. Landf. 2010, 35, 1289-1301.

19. Fang, N.F.; Shi, Z.H.; Yue, B.J.; Wang, L. The characteristics of extreme erosion events in a small mountainous watershed. PLOS ONE 2013, 8, e76610.

20. Dai, S.B.; Lu, X.X. Sediment deposition and erosion during the extreme flood events in the middle and lower reaches of the Yangtze River. Quat. Int. 2010, 226, 4-11.

21. Asselman, N.E.M. Fitting and interpretation of sediment rating curves. J. Hydrol. 2000, 234, 228-248.

22. Horowitz, A.J. An evaluation of sediment rating curves for estimating suspended sediment concentrations for subsequent flux calculations. Hydrol. Process. 2003, 17, 3387-3409.

23. Dai, Z.; Fagherazzi, S.; Mei, X.; Gao, J. Decline in suspended sediment concentration delivered by the Changjiang (Yangtze) River into the East China Sea between 1956 and 2013. Geomorphology 2016, 268, 123-132.

24. Williams, G.P. Sediment concentration versus water discharge during single hydrologic events in rivers. J. Hydrol. 1989, 111, 89-106.

25. Morehead, M.D.; Syvitski, J.P.; Hutton, E.W.H.; Peckham, S.D. Modeling the temporal variability in the flux of sediment from ungauged river basins. Global Planet. Change 2003, 39, 95-110.

26. Yeshaneh, E.; Eder, A.; Blöschl, G. Temporal variation of suspended sediment transport in the Koga catchment, North Western Ethiopia and environmental implications. Hydrol. Process. 2014, 28, 5972-5984.

27. Yang, C.T.; Stall, J.B. Unit stream power for sediment transport in natural rivers. Research Report No. 88; University of Illinois at Urbana-Champaign Water Resources Center, Illinois State Water Survey, Illinois, USA, 1974.

28. Barker, D. M.; Lawler, D. M.; Knight, D.W.; Morris, D. G.; Davies, H. N.; Stewart, E. J. Longitudinal distributions of river flood power: the combined automated flood, elevation și stream power (CAFES) methodology. Earth Surf. Process. Landf. 2009, 34, 280-290.

29. Baker, V.R.; Costa, J.E. Flood power. In Catastrophic Flooding; Mayer, L., Nash, D., Eds.; Allen and Unwin, London, UK, 1987; pp. 1-21.

30. Benito, G. Energy expenditure and geomorphic work of the cataclysmic Missoula flooding in the Columbia River Gorge, USA. Earth Surf. Process. Landf. 1997, 22, 457-472.

31. Kale, V.S.; Hire, P.S. Temporal variations in the specific stream power și total energy expenditure of a monsoonal river: The Tapi River, India. Geomorphology 2007, 92, 134-146.

32. Olariu, P.; Obreja, F.; Obreja, I. Unele aspecte privind tranzitul de aluviuni din bazinul hidrografic Trotuș și de pe sectorul inferior al râului Siret în timpul viiturilor excepționale din anii 1991 și 2005 (In Romanian). An. Univ. "Ștefan cel Mare" 2009, XVIII, 93-104. 


\section{0 of 22}

33. Dumitriu D. Geomorphic effectiveness of floods on Trotuş River channel (Romania) between 2000 and 2012. Carpath. J. of Earth Env. 2016,11,181 - 196.

34. Dumitriu, D. Sub-bankfull flow frequency versus magnitude of flood events in outlining effective discharges. Case Study: Trotuș River (Romania). Water 2018, 10, 1292.

35. Romanescu, G.; Nistor, I. The effect of the July 2005 catastrophic inundations in the Siret River's Lower Watershed, Romania. Nat. Hazards 2011, 57, 345-368.

36. Romanescu, G.; Stoleriu, C.C. Causes and effects of the catastrophic flooding on the Siret River (Romania) in July-August 2008. Nat. Hazards 2013, 69, 1351-1367.

37. Romanescu, G.; Stoleriu, C.C. Exceptional floods in the Prut basin, Romania, in the context of heavy rains in the summer of 2010. Nat. Hazards Earth Syst. Sci. 2017, 17, 381-396.

38. Romanescu, G.; Mihu-Pintilie, A.; Stoleriu, C.C.; Carboni, D.; Paveluc, L.E.; Cîmpianu, C.I. A comparative analysis of exceptional flood events in the context of heavy rains in the summer of 2010: Siret Basin (NE Romania). Case Study. Water 2018, 10, 216.

39. Dumitriu, D. Source area lithological control on sediment delivery ratio in Trotuş drainage basin (Eastern Carpathians). Geogr. Fis. Din. Quat. 2014, 37, 91-100.

40. Apostol, L. The mediterranean cyclones - the role in ensuring water resources and their potential of climatic risk, in the East of Romania. Present Env. Sust. Develop. 2008, 2, 143-163.

41. Ichim, I.; Rădoane, M.; Rădoane, N.; Grasu, C.; Miclăuş, C. Dinamica sedimentelor. Aplicație la râul Putna-Vrancea (In Romanian); Ed. Tehnică, Bucureşti, Romania, 1998; pp. 3 - 7.

42. Romanescu, G. Floods in the Siret and Pruth Basins. In Geomorphological Impacts of Extreme Weather. Case Studies from Central and Eastern Europe. Lóczy, D., Ed.; Springer; pp. 99-120.

43. Wilcock, P.R.; Crowe, J.C. Surface-based transport model for mixed-size sediment. Jour. Hydraul. Eng. 2003, 129, 120-128.

44. Rădoane, M.; Rădoane, N.; Dumitriu, D.; Miclăuș, C. Bimodality origin of fluvial bed sediments. Study case: East Carpathian rivers. Carpath. J. of Earth Env. 2006, 1, 13 -38.

45. Dumitriu, D. Sistemul aluviunilor din bazinul râului Trotuş (In Romanian); Ed. Univ., Suceava, Romania, 2007; pp. 135-155.

46. Dumitriu, D.; Condorachi, D.; Niculiță, M. Downstream variation in particle size: a case study of the Trotuş River, Eastern Carpathians (Romania). An. Univ.Oradea 2011, XXI, 222-232.

47. Chow, V.T. Open-Channel Hydraulics; McGraw-Hill: New York, NY, USA, 1959.

48. Armstrong, W.H.; Collins, M.J.; Snyder, N.P. Increased frequency of low-magnitude floods in New England. J. Am. Water Resour. Assoc. 2012, 48, 306-320.

49. Costa, J.E.; O'Connor, J.E. Geomorphically effective floods. In Natural and Anthropogenic Influences in Fluvial Geomorphology; Costa, J.E., Miller, A.J., Potter, K.W., Wilcock, P., Eds.; Am. Geophys. Union: Washington, D.C., USA, 1995; Monograph. 89, pp. 45-56.

50. Sear, D. A. Event bed load yield measurement with load cell bed load traps and prediction of bed load yield from hydrograph shape. In Erosion and Sediment Transport Measurements in Rivers: Technological and Methodological Advances; Bogen, J., Walling, D.E., Eds.; IAHS Press, Wallingford, U.K., 2004; pp.146-153.

51. Bagnold, R.A. An empirical correlation of bedload transport rates in flumes and natural rivers. Proc. R. Soc.Lond. A Math. Phys. Sci. 1980, 372, 453-473.

52. Magilligan, F.J. Thresholds and the spatial variability of flood power during extreme floods. Geomorphology 1992, 5, 373-390. 
21 of 22

53. Campbell, F.B.; Bauder, H.A. A rating-curve method for determining silt-discharge of streams. Eos Trans. AGU 1940, 21, 603-607.

54. Walling, D.E. Assessing the accuracy of suspended sediment rating curves for a small basin. Water Resour. Res. 1977, 13, 531-538.

55. Peters-Kümmerly, B.E. Untersuchungenüber Zusammensetzung und Transport von Schwebstoffen in einigen Schweizer Flüssen. Geographica Helvetica 1973, 28, 137-151.

56. Morgan, R.P.C. Soil erosion and conservation, 2nd ed.; Longman: London, UK, 1995.

57. Meade, R.H.; Moody, J.A. Causes for the decline of suspended-sediment discharge in the Mississippi river system, 1940-2007. Hydrol. Process. 2010, 24, 35-49.

58. Hickin, E.J. River geomorphology; Wiley: New York, USA, 1995.

59. Lawler, D.M.; Petts, G.E.; Foster, I.D.L.; Harper, S. Turbidity dynamics during spring storm events in an urban headwater river system: the Upper Tame, West Midlands, UK. Sci. Total Environ. 2006, 360, 109-126.

60. Syvitski, J.P.M.; Morehead, M.D.; Bahr, D.B.; Mulder, T. Estimating fluvial sediment transport: the rating parameters. Water Resour. Res. 2000, 36, 2747-2760.

61. Warrick, J.A.; Rubin, D.M. Suspended-sediment rating-curve response to urbanization and wildfire, Santa Ana River, California. J. Geophys. Res. - Earth Surf. 2007, 112, F02018.

62. Yang, G.F.; Chen, Z.; Yu, F.; Wang, Z. Sediment rating parameters and their implications: Yangtze River, China. Geomorphology 2007, 85, 166-175.

63. Huang, M.Y-F.; Montgomery, D.R. Altered regional sediment transport regime after a large typhoon, southern, Taiwan. Geology 2013, 41, 1223-1226.

64. Warrick, J.A. Trend analyses with river sediment rating curves. Hydrol. Process. 2014, 29, 936-949.

65. Fenn, C.R. Quantifying the errors involved in transferring suspended sediment rating equations across ablation seasons. Ann. Glaciol. 1989,13, 64-68.

66. Mimikou, M. An investigation of suspended sediment rating curves in western and northern Greece. Hydrolog. Sci. 1982, 27, 369-383.

67. Hu, B.; Wang, H.; Yang, Z.; Sun, X. Temporal and spatial variations of sediment rating curves in the Changjiang (Yangtze River) basin and their implications. Quat. Int. 2011, 230, 34-43.

68. Fan, X.; Shi, C.; Shao, W.; Zhou, Y. The suspended sediment dynamics in the Inner-Mongolia reaches of the upper Yellow River. Catena 2013, 109, 72-82.

69. Vaughan, A.A.; Belmont, P.; Hawkins, C.P.; Wilcock, P. Near-channel versus watershed controls on sediment rating curves. J. Geophys. Res. Earth Surf. 2017, 122, 1901-1923.

70. Bača, P. Hysteresis effect in suspended sediment concentration in the Rybárik basin, Slovakia/Effet d'hystérèse dans la concentration des sédiments en suspension dans le bassin versant de Rybárik (Slovaquie). Hydrol. Sci. J. 2008, 53, 224-235.

71. Lenzi, M.A.; Marchi, L. Suspended sediment load during floods in a small stream of the Dolomites (north eastern Italy). Catena 2000, 39, 267-282.

72. Rovira, A.; Batalla, R.J. Temporal distribution of suspended sediment transport in a Mediterranean basin: the Lower Tordera (NE Spain). Geomorphology 2006, 79, 58-71.

73. Hu, J.; Gao, P.; Mu, X.; Zhao G.; Sun, W.; Li, P.; Zhang, L. Runoff-sediment dynamics under different flood patterns in a Loess Plateau catchment, China. Catena 2019, 173, 234-245.

74. Klein, M. Anti clockwise hysteresis in suspended sediment concentration during individual storms: Holbeck catchment, Yorkshire England. Catena 1984, 11, 251-257. 


\section{2 of 22}

75. Bisantino, T.; Gentile, F.; Liuzzi G.T. Continuous monitoring of suspended sediment load in semi-arid environments. In Sediment Transport; Ginsberg, S.S., Ed.; InTech Open Access: Rijeka, Croatia, 2011; pp. 295-312.

76. Martin, S.E.; Conklin, M.H.; Bales, R.C. Seasonal accumulation and depletion of local sediment stores of four headwater catchments. Water 2014, 6, 2144-2163.

77. Lana-Renault, N.; Regüés, D. Seasonal patterns of suspended sediment transport in an abandoned farmland catchment in the Central Spanish Pyrenees. Earth Surf.Process. Landf. 2009, 34, 1291-1301.

78. Milan, D.J. Geomorphic impact and system recovery following an extreme flood in an upland stream: Thinhope Burn, northern England, UK. Geomorphology 2012, 138, 319-328.

79. Baggs Sargood, M. Hitting rock bottom: Morphological response of upland bedrock-confined streams to catastrophic flooding, Bachelor of Environmental Science (Honours), School of Earth \& Environmental Science, University of Wollongong, 2013.

80. Smith, J.D. The role of riparian shrubs in preventing floodplain unraveling along the Clark Fork of the Columbia River in the Deer Lodge Valley, Montana. In Riparian vegetation and fluvial geomorphology; Bennett, S.J., Simon, A., Eds.; American Geophysical Union, 2013; pp. 71-85.

81. Magilligan, F.J.; Buraas, E.; Renshaw, C. The efficacy of streampower and flow duration on geomorphic responses to catastrophic flooding. Geomorphology 2015, 228, 175-188.

82. Mao, L. The effects of flood history on sediment transport in gravel-bed rivers. Geomorphology 2018, 322, 196-205.

83. Phillips, C.B.; Hill, K.M.; Paola, C.; Singer, M.B.; Jerolmack, D.J. Effect of flood hydrograph duration,magnitude, and shape on bed load transport dynamics. Geophys. Res. Lett. 2018, 45, 8264-8271.

84. Mrokowska, M.M.; Rowiński, P.M. Impact of unsteady flow events on bedload transport: a review of laboratory experiments. Water 2019, 11, 907.

85. Huang, H.Q.; Nanson, G.C. Hydraulic geometry and maximum flow efficiency as products of the principle of least action. Earth Surf. Process. Landf. 2000, 25, 1-16.

86. Huang, H.Q.; Nanson, G.C. A stability criterion inherent in laws governing alluvial channel flow. Earth Surf. Process. Landf. 2002, 27, 929-944.

87. Bawa, N.; Jain, V.; Shekhar, S.; Kumar, N.; Jyani, V. Controls on morphological variability and role of stream power distribution pattern, Yamuna River, western India. Geomorphology 2014, 227, 60-72. 